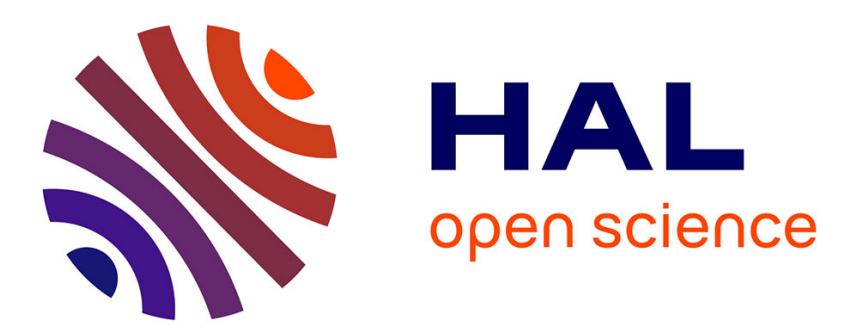

\title{
Interaction of Cisplatin with 5'-dGMP: A Combined IRMPD and Theoretical Study
}

Barbara Chiavarino, Maria Elisa Crestoni, Simonetta Fornarini, Debora

Scuderi, Jean-Yves Salpin

\section{> To cite this version:}

Barbara Chiavarino, Maria Elisa Crestoni, Simonetta Fornarini, Debora Scuderi, Jean-Yves Salpin. Interaction of Cisplatin with 5'-dGMP: A Combined IRMPD and Theoretical Study. Inorganic Chemistry, 2015, 54 (7), pp.3513-3522. 10.1021/acs.inorgchem.5b00070 . hal-01221291

\section{HAL Id: hal-01221291 \\ https://hal.science/hal-01221291}

Submitted on 5 Oct 2018

HAL is a multi-disciplinary open access archive for the deposit and dissemination of scientific research documents, whether they are published or not. The documents may come from teaching and research institutions in France or abroad, or from public or private research centers.
L'archive ouverte pluridisciplinaire HAL, est destinée au dépôt et à la diffusion de documents scientifiques de niveau recherche, publiés ou non, émanant des établissements d'enseignement et de recherche français ou étrangers, des laboratoires publics ou privés. 


\section{Interaction of cisplatin with 5'-dGMP: a combined IRMPD and theoretical study}

Barbara Chiavarino ${ }^{1 *}$, Maria Elisa Crestoni ${ }^{1}$, Simonetta Fornarini ${ }^{1}$, Debora Scuderi ${ }^{2,3}$ and Jean-Yves Salpin ${ }^{4,5 *}$

1)Dipartimento di Chimica e Tecnologie del Farmaco, Università di Roma "La Sapienza", P.le A. Moro 5, I-00185 Roma, ITALY

2) Université Paris Sud Orsay - Laboratoire de Chimie-Physique - Avenue Georges Clémenceau - 91405 Orsay Cedex - FRANCE

3) CNRS- UMR 8000.

4) Université d'Evry Val d'Essonne - Laboratoire Analyse et Modélisation pour la biologie et l'Environnement - Boulevard François Mitterrand - 91025 Evry - FRANCE

5) CNRS- UMR 8587.

\section{Corresponding authors:}

Dr Barbara Chiavarino

e-mail: barbara.chiavarino@uniroma1.it

Dr Jean-Yves Salpin

e-mail: jean-yves.salpin@univ-evry.fr 


\section{Abstract}

IR Multiple Photon Dissociation (IRMPD) spectroscopy of cis- $\left[\mathrm{Pt}\left(\mathrm{NH}_{3}\right)_{2}\left(5^{\prime} \text {-dGMP-H) }\right]^{+}\right.$and cis- $\left[\mathrm{PtCl}\left(\mathrm{NH}_{3}\right)_{2}\left(5^{\prime} \text {-dGMP }\right)\right]^{+}$ions (where (5'-dGMP) is 2'-deoxyguanosine- $5^{\prime}-$ monophosphate), generated in the gas phase by electrospray ionization, has been performed in two spectral regions, namely $700-1900 \mathrm{~cm}^{-1}$ and $2800-3800 \mathrm{~cm}^{-1}$. For structural assignment, experimental IRMPD spectra were compared to IR spectra computed at the B3LYP/LACV3P/6-311G** level of theory. In agreement with computational results, the vibrational spectroscopic characterization of the cis- $\left[\mathrm{Pt}\left(\mathrm{NH}_{3}\right)_{2}\left(5^{\prime}-\mathrm{dGMP}-\mathrm{H}\right)\right]^{+}$ion points to macrochelate species resulting from the simultaneous interaction of the metal with both the $\mathrm{N} 7$ atom of the guanine residue and an $\mathrm{O}$ atom of the phosphate group, structures that bear feature in common with those characterized in solution by NMR spectroscopy. Concerning the cis-[PtCl$\left.\left(\mathrm{NH}_{3}\right)_{2}\left(5^{\prime}-\mathrm{dGMP}\right)\right]^{+}$ion, our study points to a monodentate complex involving exclusively the N7 position of guanine, as observed in solution. Also this species exhibits a compact form due to the formation of two hydrogen bonds involving the same ammonia ligand. For both complexes, IRMPD experiments show that a strong intramolecular hydrogen bond is established between one ammonia hydrogen and the carbonyl group of guanine. The strength of this particular interaction can be qualitatively estimated by looking at the redshift of the $\mathrm{CO}$ vibration with respect to an unperturbed $\mathrm{C}=\mathrm{O}$ stretching mode in the fingerprint region. This point is also highlighted in the $X-H(X=N, O)$ stretch region, by the shift of the $\mathrm{N}-\mathrm{H}$ stretch frequency as a function of the number of hydrogen bonds involving the ammonia ligand. 


\section{Introduction.}

Cisplatin (cis-diamminedichloroplatinum(II)) has been one of the most widely prescribed drug for many cancer diseases, especially against testicular, ovarian, head, and neck cancer. ${ }^{1}$ Although its mechanism of action has not yet been fully elucidated, it is generally accepted that the therapeutic activity of cisplatin is achieved by binding with DNA to form crosslinks as major lesions, thus inhibiting replication and transcription processes and finally the cell's repair mechanism..$^{2-5}$

With this paper, we continue the experimental structural characterization of ionic complexes from cisplatin and DNA components in the gas phase by combining IRMPD (Infrared Multiple Photon Dissociation) spectroscopy of complexes generated in a mass spectrometer by electrospray ionization (ESI), to theoretical DFT calculations. As illustrated by our previous studies, we chose a strategy based upon the gradual increase of the size of the nucleic acid building blocks. We have first characterized the biologically active form of cisplatin, namely cis-[PtCl$\left.\left(\mathrm{NH}_{3}\right)_{2}\left(\mathrm{H}_{2} \mathrm{O}\right)\right]^{+}$, formed within the cell by a ligand exchange process promoted by the low intra-cell chloride concentration. ${ }^{6}$ We have then provided a detailed characterization of the cis- $\left[\mathrm{PtCl}\left(\mathrm{NH}_{3}\right)_{2}(\mathrm{G})\right]^{+}$and $c i s-\left[\mathrm{PtCl}\left(\mathrm{NH}_{3}\right)_{2}(\mathrm{~A})\right]^{+}$complexes (where $\mathrm{G}$ is guanine and $\mathrm{A}$ is adenine), the simplest models of the monofunctional adducts between cisplatin and the nucleobases of DNA. ${ }^{7}$

Proceeding with increasing complexity of the ligand, we presently report a study of the interaction of cisplatin with 2'-deoxyguanosine-5'-monophosphate (5'-dGMP). Moving from the simple nucleobase to the mononucleotide, the possible binding sites of cisplatin increase. In addition to the N7 position of guanine, platinum may interact with the oxygen(s) of the phosphate group and with the hydroxyl group of the deoxyribose moiety. Figure 1 shows the structure of 5'-dGMP. Due to the greater flexibility of the nucleotide as compared to the 
nucleobase, many conformers are possible depending in particular on the rotation of the nucleobase about the $\mathrm{N}$-glycosidic bond and on the ribose ring-puckering. As a matter of fact, the nucleotide may be either in syn (anti) conformation when the amino group of the G residue is oriented toward (away from) the phosphate group. Regarding the sugar ringpuckering, the "south" (S) structures are those with the C2'-endo conformation, while the “north" $(\mathrm{N})$ ones present a C3'-endo conformation.

\section{$<$ Figure 1 >}

Two ions were presently considered for their structural characterization by IRMPD spectroscopy, namely the cis-[Pt( $\left.\left(\mathrm{NH}_{3}\right)_{2}\left(5^{\prime}-\mathrm{dGMP}-\mathrm{H}\right)\right]^{+}$and $c i s-\left[\mathrm{PtCl}\left(\mathrm{NH}_{3}\right)_{2}\left(5^{\prime}-\mathrm{dGMP}\right)\right]^{+}$ complexes. The former has been previously characterized by a combined NMR and theoretical study. ${ }^{8,9}$ Results of these previous studies have postulated a macrochelate structure for the $c i s-\left[\mathrm{Pt}\left(\mathrm{NH}_{3}\right)_{2}\left(5^{\prime}-\mathrm{dGMP}\right)-\mathrm{H}\right]^{+}$complex, where the nucleotide is bound to the cis- $\left[\mathrm{Pt}\left(\mathrm{NH}_{2} \mathrm{R}\right)_{2}\right]$ moiety $\left(\mathrm{R}=\mathrm{H}, \mathrm{CH}_{3}\right)$ via $\mathrm{N} 7$ and an $\mathrm{O}$ of the phosphate group, with a anti orientation of the nucleobase and a strong preference for an North sugar conformation. The characterization of $c i s-\left[\mathrm{PtCl}\left(\mathrm{NH}_{3}\right)_{2}\left(5^{\prime} \text {-dGMP }\right)\right]^{+}$, that models the first species resulting from attack of cisplatin to DNA, is more complicated. cis- $\left[\mathrm{PtCl}\left(\mathrm{NH}_{3}\right)_{2}\left(5^{\prime}-\mathrm{dGMP}\right)\right]^{+}$is a transient complex which further reacts for example by loss of $\mathrm{HCl}$. In a previous NMR study of this particular complex, the lack of protonation onto the N7 position of GMP indicated that platinum was bound to the N7 atom of the guanine residue. ${ }^{10,11}$ Presently, the use of ESI coupled to mass spectrometry in order to isolate the complex of interest generated in solution is very helpful for studying short-lived ions in the gas phase. ${ }^{12-15}$ Furthermore, the coupling of a mass spectrometer to intense infrared sources allows one to obtain the structural characterization of the ion of interest. Two distinct energy ranges were considered. First, 
IRMPD spectra were recorded in the fingerprint region (700-1900 $\left.\mathrm{cm}^{-1}\right)$ using an IR free electron laser. Subsequently, the vibrational modes associated with the $\mathrm{CH}, \mathrm{NH}$ and $\mathrm{OH}$ stretches were also investigated by recording IRMPD spectra in the $2800-3800 \mathrm{~cm}^{-1}$ frequency range, using an optical parametric oscillator (OPO/OPA) laser. The latter spectral range is of particular interest for probing the vibrational shifts associated with stretches involved in hydrogen bonds.

\section{Experimental}

\subsection{Materials}

Cisplatin and 5'-dGMP used in this work were research grade products from commercial sources (Sigma-Aldrich s.r.l. Milan, Italy) and were used without further purification. In order to generate the complexes of interest, stock solutions of either cisplatin or 5'-dGMP, both in the $\mathrm{mM}$ range in purified water, were prepared, mixed in 1:1 molar ratio and diluted with water to reach the final concentration of $5 \cdot 10^{-5} \mathrm{M}$ in each analyte..

\subsection{IRMPD experiments}

The complexes of interest have been obtained as gaseous species by ESI of water solutions prepared as described. Typical ESI conditions were a flow rate of 2-4 $\mu \mathrm{L} / \mathrm{min}$, capillary spray voltage at $-4.5 \mathrm{kV}$, nebulizer at $12 \mathrm{PSI}$, drying gas flow at $5 \mathrm{~L} / \mathrm{min}$, and drying gas temperature at $300^{\circ} \mathrm{C}$.

IRMPD spectroscopy in the $700-1900 \mathrm{~cm}^{-1}$ frequency range (the so-called fingerprint region) has been performed at the beamline of the free electron laser (FEL) of the Centre Laser Infrarouge d'Orsay (CLIO). For the present study, the electron energy of the FEL was set at 36 and $45 \mathrm{MeV}$ in two distinct runs, in order to optimize the laser power in the frequency 
region of interest. FEL-based experiments were performed by coupling of the FEL beamline with a hybrid FT-ICR tandem mass spectrometer (APEX-Qe Bruker Daltonics) ${ }^{16,17}$, equipped with a 7.0 T actively shielded magnet and a quadrupole-hexapole interface for mass-filtering and ion accumulation, under the control of the commercial software APEX 1.0. Mass selection of the cis-[PtCl$\left.\left(\mathrm{NH}_{3}\right)_{2}\left(5^{\prime}-\mathrm{dGMP}\right)\right]^{+}$and $c i s-\left[\mathrm{Pt}\left(\mathrm{NH}_{3}\right)_{2}\left(5^{\prime}-\mathrm{dGMP}\right)-\mathrm{H}\right]^{+}$ions was performed in the quadrupole, and ions were accumulated in the hexapole containing argon (buffer gas) for $0.5 \mathrm{~s}$ for collisional cooling prior to their transfer into the ICR cell. The isolated charged complexes were then irradiated for $100 \mathrm{~ms}$ to $420 \mathrm{~ms}$ with the IR FEL light, after which the resulting ions were mass-analyzed.

To record the spectra of the different complexes in the $2800-3800 \mathrm{~cm}^{-1}$ spectral region, an Optical Parametric Oscillator/Amplifier (OPO/OPA) (LaserVision) laser system coupled to a Paul ion trap mass spectrometer (Esquire 6000+, Bruker Daltonics), has been employed as described previously. ${ }^{18}$ The typical output energy from the OPO/OPA laser was $20 \mathrm{~mJ} /$ pulse in the investigated spectral range with $3-4 \mathrm{~cm}^{-1}$ bandwidth. In the trap, ions were massselected and accumulated for 5-10 ms prior to IR irradiation. The irradiation time used in the experiment varies from 0.5 to $4 \mathrm{~s}$.

IRMPD spectra are obtained by plotting the photofragmentation yield $\mathrm{R}\left(\mathrm{R}=-\ln \left[I_{\text {parent }} /\left(I_{\text {parent }}\right.\right.\right.$ $\left.\left.+\Sigma I_{\text {fragment }}\right)\right]$ ), where $I_{\text {parent }}$ and $I_{\text {fragment }}$ are the integrated intensities of the mass peaks of the precursor and of the fragment ions, respectively) as a function of the frequency of the IR radiation. ${ }^{16}$ A recent study has established that this data treatment gives better comparison with calculated infrared absorption spectra and a better spectral resolution than other analysis methods, such as calculating a photodissociation yield or recording a depletion spectrum of the parent ion abundance. ${ }^{19}$ 


\subsection{Computational Details}

Molecular orbital calculations were carried out using the B3LYP density functional, ${ }^{20,21}$ as implemented in the Gaussian-09 set of programs. ${ }^{22}$ The different species considered have been optimized using the $6-311 \mathrm{G}^{* *}$ basis set, without any symmetry constraint. In order to describe the metallic center, we used the Los Alamos effective core potential (ECP) in combination with the LACV3P** basis set. $^{23-25}$ Harmonic vibrational frequencies were estimated at this level in order to characterize the stationary points as local minima or saddle points, and to estimate the zero-point vibrational energy (ZPE) corrections. In the perspective of studying bigger systems, B3LYP/6-31G** calculations have been also performed, Pt being described either with the SKBJ ECP+basis sets ${ }^{26}$ or the LANL2DZ approach. ${ }^{23-25}$ It turned out that both the relative energies and vibrational spectra are similar, regardless of the pseudopotential and basis sets used to perform the calculations.

The infrared absorption spectra of the various structures were calculated within the harmonic approximation. All calculated frequencies were scaled by a factor of 0.974 and 0.957 in the fingerprint and $\mathrm{X}-\mathrm{H}$ stretch regions, respectively, for a better agreement with the experimental spectrum. These scaling factor were previously adopted for the related simpler complexes cis$\left[\mathrm{PtCl}\left(\mathrm{NH}_{3}\right)_{2} \mathrm{G}\right]^{+}$and cis- $\left[\mathrm{PtCl}\left(\mathrm{NH}_{3}\right)_{2} \mathrm{~A}\right]^{+}$, with good results. ${ }^{7}$ However, a separate discussion is required for the IR modes involving the phosphate group. As reported in previous papers, the scaling factors generally adopted for the other vibrations are systematically too low for the vibrational modes of the $\mathrm{P}-\mathrm{OC}, \mathrm{P}-\mathrm{OH}$ and $\mathrm{P}=\mathrm{O}$ bonds belonging to the phosphate group, when compared to the experimental frequencies. This has been recently noticed during the study of different biomolecular ions, such as phosphorylated amino acids, ${ }^{27}{ }^{28}$ peptides, ${ }^{29}$ and nucleotides. $^{30-32}$ In a recent publication, ${ }^{32}$ a scaling factor of 0.974 was chosen for the vibrations above $1300 \mathrm{~cm}^{-1}$, and no scaling for vibrations below $1300 \mathrm{~cm}^{-1}$, the phosphate $(\mathrm{P}-$ 
$\mathrm{OH}, \mathrm{P}=\mathrm{O}$ and $\mathrm{P}-\mathrm{OC}$ ) stretches region. In all the cases reported, it seems that the scaling factor should be even greater than one. Given these considerations, we decided in the present study to use a scaling factor of 0.974 for all the IR frequencies in the fingerprint region, and no scaling factor (that is 1 ) only for the frequencies involving the $\mathrm{P}=\mathrm{O}, \mathrm{P}-\mathrm{OH}$ and $\mathrm{P}-\mathrm{OC}$ modes of the phosphate group. For the sake of comparison with experimental data, calculated IR spectra were convoluted with a lorentzian profile of $20 \mathrm{~cm}^{-1}$ (fwhm) in the fingerprint region and of $5 \mathrm{~cm}^{-1}$ in the in the $\mathrm{X}-\mathrm{H}$ stretch region.

Throughout this paper, total energies are expressed in Hartrees and relative energies in $\mathrm{kJ}$ $\mathrm{mol}^{-1}$. For the sake of simplicity, the basis set used will be referred to as $6-311 \mathrm{G}^{* *}$ henceforth. Detailed geometries (Cartesian coordinates) of all the structures mentioned in this paper are available from the authors upon request.

\section{Results and Discussion}

Formation of both cis- $\left[\mathrm{PtCl}\left(\mathrm{NH}_{3}\right)_{2}\left(5^{\prime}-\mathrm{dGMP}\right)\right]^{+}$and $c i s-\left[\mathrm{Pt}\left(\mathrm{NH}_{3}\right)_{2}\left(5^{\prime}-\mathrm{dGMP}-\mathrm{H}\right)\right]^{+}$adducts is obtained upon mixing the two solutions containing cisplatin and 2'-deoxyguanosine-5'monophosphate. When a solution of cisplatin and 5'-dGMP in 1:1 ratio is analysed, soon after mixing, under usual ESI conditions, an intense signal is observed at $\mathrm{m} / \mathrm{z}, 610-614$ consistent with the formation of $c i s-\left[\mathrm{PtCl}\left(\mathrm{NH}_{3}\right)_{2}\left(5^{\prime}-\mathrm{dGMP}\right)\right]^{+}$. A second albeit less abundant ion at $\mathrm{m} / \mathrm{z}$ 574-578 corresponding to the cis- $\left[\mathrm{Pt}\left(\mathrm{NH}_{3}\right)_{2}\left(5^{\prime}-\mathrm{dGMP}-\mathrm{H}\right)\right]^{+}$complex is also present in the mass spectrum. After $24 \mathrm{~h}$, the $c i s-\left[\mathrm{Pt}\left(\mathrm{NH}_{3}\right)_{2}\left(5^{\prime}-\mathrm{dGMP}-\mathrm{H}\right)\right]^{+}$complex becomes predominant. The complexes of interest are formed together with other species containing 5'-dGMP derivatives bound with cisplatin ions, as reported previously. ${ }^{7}$ The simultaneous presence of one platinum atom and one chlorine within the complex yields a characteristic isotopic pattern 
for the cluster at $m / z$ 610-614, easily distinguishable from any Pt-complex devoid of a chlorine atom, as in the case of the ion at $m / z$ 574-578.

\subsection{IRMPD spectroscopy of $c i s-\left[\mathrm{Pt}\left(\mathrm{NH}_{3}\right)_{2}\left(5^{\prime} \text {-dGMP)-H }\right]^{+}\right.$}

During the last decade, IRMPD spectroscopy has been successfully applied to elucidate the structure of numerous ions from very simple fundamental species to (bio)molecular and composite cluster ions. ${ }^{12,14,31-50} \mathrm{We}$ presently applied this approach to characterize the structure of $c i s-\left[\mathrm{Pt}\left(\mathrm{NH}_{3}\right)_{2}\left(5^{\prime}-\mathrm{dGMP}\right)-\mathrm{H}\right]^{+}$. To this end, the whole isotopic cluster corresponding to the cis- $\left[\mathrm{Pt}\left(\mathrm{NH}_{3}\right)_{2}\left(5^{\prime}-\mathrm{dGMP}\right)-\mathrm{H}\right]^{+}$ion $(\mathrm{m} / z, 574-578)$ was isolated in the FTICR mass spectrometer, and submitted to IRMPD spectroscopy. The fragmentation of cis$\left[\mathrm{Pt}\left(\mathrm{NH}_{3}\right)_{2}\left(5^{\prime}-\mathrm{dGMP}-\mathrm{H}\right)\right]^{+}$upon irradiation by IR photons in resonance with an active vibrational mode yields four major fragment ions, namely a cluster at $\mathrm{m} / \mathrm{z} 556-559$, that includes two different species, corresponding to the loss of either water $(\mathrm{m} / \mathrm{z} 556-558)$ or ammonia $\left(m / z\right.$ 557-559), respectively, a cluster at $m / z$ 539-543 (the combined loss of $\mathrm{NH}_{3}$ and $\mathrm{H}_{2} \mathrm{O}$ ), an ion $m / z$ 522-526 resulting from the loss of two ammonia and one water molecules, and a cluster at $m / z$ 441-445 due to loss of $\mathrm{NH}_{3}$ together with the sugar residue (deoxyribosyl unit). (Figure $\mathrm{S} 1$ of the supporting information) In the last process, a complex where platinum is coordinated to ammonia, meta-phosphoric acid and a deprotonated guanine residue is formally obtained, namely $\left[\mathrm{Pt}\left(\mathrm{NH}_{3}\right)\left(\mathrm{HPO}_{3}\right)(\mathrm{G})-\mathrm{H}\right]^{+}$. The formation of this particular fragment might suggest that in the cis-[Pt( $\left.\left(\mathrm{NH}_{3}\right)_{2}\left(5^{\prime}-\mathrm{dGMP}-\mathrm{H}\right)\right]^{+}$complex the 5'-dGMP ligand may act as a chelating agent coordinating the metallic centre with both guanine and an oxygen of the phosphate group, so giving a cyclic structure including Pt. This coordination is possible because platinum(II) in $\left[\mathrm{Pt}\left(\mathrm{NH}_{3}\right)\right]^{2+}$ owns two free coordination sites at variance with $\left[\operatorname{PtCl}\left(\mathrm{NH}_{3}\right)_{2}\right]^{+}$forming the $c$ is $-\left[-\left[\mathrm{PtCl}\left(\mathrm{NH}_{3}\right)_{2}\left(5^{\prime}-\mathrm{dGMP}\right)\right]^{+}\right.$species. In our previous IRMPD study on cis-[PtCl$\left.\left(\mathrm{NH}_{3}\right)_{2}(\mathrm{G})\right]^{+}$, similarly generated, we have found that the coordination site 
of platinum is the N7 atom of guanine, ${ }^{7}$ confirming previous theoretical predictions on the interaction between cisplatin and guanine. ${ }^{51,52}$ So, it is reasonable to assume that one of the platination site is on the guanine residue. Another possible platination site could be an oxygen atom of the phosphoric moiety. Other minor fragment ions observed in the IRMPD experiments are the isotopic clusters associated with loss of water, ammonia and guanine $(\mathrm{m} / \mathrm{z}$ 388-392). Finally, in the fragment detected at $m / z$ 378-382, only the nucleobase of 5'-dGMP remains attached to $\left[\mathrm{Pt}\left(\mathrm{NH}_{3}\right)_{2}\right]^{+}$as deprotonated guanine.

Aiming to obtain information about the structural features of the complex at $\mathrm{m} / \mathrm{z} 574-578$, IRMPD spectra recorded in both spectral regions were compared to the calculated IR spectra of candidate structures for the $c i s-\left[\mathrm{Pt}\left(\mathrm{NH}_{3}\right)_{2}\left(5^{\prime}-\mathrm{dGMP}-\mathrm{H}\right)\right]^{+}$complex. The various species are classified according to the platinum coordination scheme. The lowest energies structures obtained for this system are presented in Figure 2 together with their relative free energies at 298 K. A complete scheme with all the species investigated (showing relative free energies, coordination mode, ring puckering, orientation of the guanine unit, internal hydrogen bonding) is provided in the Supporting Information.

\section{< Figure 2 >}

The first family of structures, namely PtdGMP_A, is associated with a bidentate interaction of the deprotonated phosphate group with the metal in the $\left(\mathrm{NH}_{3}\right)_{2} \mathrm{Pt}$ moiety. Though being a minimum, this structure is rather high in energy $\left(+167.9 \mathrm{~kJ} \mathrm{~mol}^{+}\right)$. Bidentate coordination with both the deprotonated phosphate group and $O\left(3^{\prime}\right) H$ hydroxyl group (PtdGMP_G), reported in Figure S3 of the Supporting Information, does not result in a more stable species 
$\left(+177.0 \mathrm{~kJ} \mathrm{~mol}^{-1}\right.$ with respect to the global minimum). We also considered deprotonation of the $\mathrm{O}\left(3^{\prime}\right) \mathrm{H}$ group. Interaction of platinum with $\mathrm{O}\left(3^{\prime}\right)^{-}$and the phosphoryl $(\mathrm{P}=0)$ group (PtdGMP_In) gives rise to slightly more stable isomers. On the other hand, replacement of the phosphoryl group by the phosphohydroxyl ( $\mathrm{P} O \mathrm{OH})$ induces a significant destabilization (PtdGMP_H in Figure S3; at $+218.7 \mathrm{~kJ} \mathrm{~mol}^{-1}$ ).

As shown by the relative free energies at $298 \mathrm{~K}$ reported in both Table S1 and Figure 2, the most stable structures (PtdGMP_Dn) correspond to macrochelate complexes where the cis$\left[\mathrm{Pt}\left(\mathrm{NH}_{3}\right)_{2}\right]^{2+}$ unit is coordinated to both the N7 position of guanine and the deprotonated oxygen of the phosphate group. Clearly, the interaction with N7 provides an important stabilization. All these forms are also characterized by a strong hydrogen bond established between one $\mathrm{NH}_{3}$ ligand and the carbonyl group of guanine. The global minimum corresponds to the PtdGMP_D5 syn structure. Slightly less stable is PtdGMP_D6 (+2.6 kJ mol $^{-1}$ ) which shares with PtdGMP_D5 the same characteristics except for the nucleobase orientation (anti). PtdGMP_D4 only differs from PtdGMP_D5 by the rotation of the phosphate group and lies at $3.6 \mathrm{~kJ} \mathrm{~mol}^{-1}$ above the global minimum. These three forms all adopt a North sugar conformation (see Supporting Information for more details). PtdGMP_D3 is also characterized by a syn-oriented guanine, but adopts a slightly less favorable ring puckering $\left(\mathrm{C}^{\prime}\right.$ '-endo/C3'-exo; $\left.+21.4 \mathrm{~kJ} \mathrm{~mol}^{-1}\right)$. Two other macrochelates were located, namely PtdGMP_D1 and PtdGMP_D2, which are of similar stability as PtdGMP_D3 but present a different nucleobase orientation (anti). Comparison of PtdGMP_Dn forms with the PtdGMP_F structure $\left(+73.4 \mathrm{~kJ} \mathrm{~mol}^{-1}\right)$, in which the platinum ion interacts with both the deprotonated phosphate group and the carbonyl oxygen (O6) of guanine, further confirms the N7 centre of guanine as the most favourable coordination site. 
A brief description of some other representative structure for the cis-[Pt( $\left.\mathrm{NH}_{3}\right)_{2}\left(5^{\prime}-\mathrm{dGMP}-\right.$ $\mathrm{H})]^{+}$complex is provide in the Supporting Information.

We also tried to optimize strutures for which the cis $\left[\mathrm{P} t\left(\mathrm{NH}_{3}\right)_{2}\right]^{2+}$ tnit only interacts with $\mathrm{N} 7$. During optimization, these forms evolve either by proton transfer between an ammonia group and the deprotonated phosphate (PtdGMP_Cn) or towards a bidentate interaction involving both N7 and the phosphate (PtdGMP_D forms). Finally, we also envisaged coordination ont the N3 position of guanine. The most stable structure found and reported in this paper (PtdGMP_J1, Figure 2) implies a C1'exo ring puckering, which, associated with the syn orientation of the guanine residue, allows the simultaneous interaction with the deprotonated phosphate. This structure is located at $91.2 \mathrm{~kJ} \mathrm{mot}^{-1}$ above the global minimum.

The IRMPD spectra of cis-[Pt( $\left.\left(\mathrm{NH}_{3}\right)_{2}\left(5^{\prime}-\mathrm{dGMP}-\mathrm{H}\right)\right]^{+}$recorded in the $700-1900$ and 2800$3800 \mathrm{~cm}^{-1}$ spectral range are reported in the lower panel of Figure 3, together with the calculated IR spectra of some exemplary species among the ones displayed in Figure 2.

\section{$<$ Figure 3 >}

In the fingerprint domain, the IRMPD spectrum of cis-[Pt( $\left.\left(\mathrm{NH}_{3}\right)_{2}\left(5^{\prime}-\mathrm{dGMP}-\mathrm{H}\right)\right]^{+}$presents distinct features at 1021, 1095, 1283, 15821627 and $1701 \mathrm{~cm}^{-1}$ (figure 3a). Other weaker bands are found at 902, 931, 1169, 1198, 1367 and $1516 \mathrm{~cm}^{-1}$. In the $\mathrm{X}-\mathrm{H}(\mathrm{X}=\mathrm{C}, \mathrm{N}, \mathrm{O})$ stretching range, the IRMPD spectrum of cis-[Pt( $\left.\left.\mathrm{NH}_{3}\right)_{2}\left(5^{\prime}-\mathrm{dGMP}-\mathrm{H}\right)\right]^{+}$shows two sharp bands at 3422 and $3672 \mathrm{~cm}^{-1}$ and a broad band at 3439-3453 $\mathrm{cm}^{-1}$. A few weaker absorptions are detected at ca. 2919-2984, 3156, 3381 and $3557 \mathrm{~cm}^{-1}$. The calculated spectra of PtdGMP_D4-6 provide the best fit with the experimental spectrum (Figure 3). Thus, the vibrational modes of cis- $\left[\mathrm{Pt}\left(\mathrm{NH}_{3}\right)_{2}\left(5^{\prime}-\mathrm{dGMP}-\mathrm{H}\right)\right]^{+}$can be assigned as described in Table 1, 
which lists the experimental IRMPD features together with the calculated IR bands of the global minimum PtdGMP_D5. Focusing on the main absorptions in the fingerprint range, the pronounced and broad experimental band at $1021 \mathrm{~cm}^{-1}$ can be assigned to the feature centered at $993 \mathrm{~cm}^{-1}$ comprising several vibrational modes, calculated at 976, 991, 994, and $1019 \mathrm{~cm}^{-1}$ associated to stretches of the $\mathrm{O}-\mathrm{P}=\mathrm{O}-\mathrm{Pt}$ unit, $\mathrm{PO}-\mathrm{H}$ bending, and to the furanosic ring breathing. The feature at $1283 \mathrm{~cm}^{-1}$ can be assigned to two active modes, namely the $\mathrm{P}=\mathrm{O}$ stretching mode at $1276 \mathrm{~cm}^{-1}$ and the umbrella mode of $\mathrm{NH}_{3}$ not involved in hydrogen bonding with the carbonyl oxygen (O6) of the guanine, at $1287 \mathrm{~cm}^{-1}$. The three major features at 1582,1627 and $1701 \mathrm{~cm}^{-1}$ are the characteristic signature of the coordination of the cis$\left[\mathrm{Pt}\left(\mathrm{NH}_{3}\right)_{2}\right]^{2+}$ moiety onto the N7 position of guanine, as previously observed for the cis$\left[\mathrm{PtCl}\left(\mathrm{NH}_{3}\right)_{2}(\mathrm{G})\right]^{+}$complex. ${ }^{7}$ Indeed, as shown in Figure 3(b-e), these three features are present in all computed spectra for PtdGMP_Dn $(n=1,4,5,6)$, in which one of the platination site by the $c i s-\left[\mathrm{Pt}\left(\mathrm{NH}_{3}\right)_{2}\right]^{2+}$ unit is the nitrogen $\mathrm{N} 7$ of guanine. The first band at $1582 \mathrm{~cm}^{-1}$ can be assigned to $\mathrm{NH}_{2}$ scissoring combined with the stretching of several purine ring bonds. The second feature can be attributed to the combination of different $\mathrm{NH}_{2}$ scissoring modes, and the last one to the $\mathrm{CO}$ stretch of guanine. These modes are computed at 1582, 1635 and $1699 \mathrm{~cm}^{-1}$ respectively, for PtdGMP_D5. The relatively low wavenumber associated with the carbonyl stretch is explained by the strong hydrogen bond established between the carbonyl oxygen and a hydrogen atom of one ammonia ligand of the $\left[\mathrm{Pt}\left(\mathrm{NH}_{3}\right)_{2}\right]^{2+}$ unit, favored when platinum is bound to the N7 position. This strong hydrogen bond decreases the force constant of the $\mathrm{C}=\mathrm{O}$ bond causing a redshift in the absorption frequency with respect to an unperturbed $\mathrm{C}=\mathrm{O}$ bond. In PtdGMP_F and PtdGMP_B2 (Figure S4 of the supporting information) where the metal interacts directly with the guanine carbonyl group, the CO stretch is calculated at 1449 and $1512 \mathrm{~cm}^{-1}$ respectively, indicative of a 
strongly weakened bond. Note that the very intense feature $\left(1853 \mathrm{~cm}^{-1}\right)$ associated with the NH stretch in the spectrum of PtdGMP_B2 is not observed experimentally, disproving any contribution of this particular isomer.

Now considering the $\mathrm{X}-\mathrm{H}$ stretch region, the calculated spectra do not reproduce the experimental data (figure 3a') quite well. In particular, one notices the absence of few small absorptions pertaining to the symmetric and antisymmetric stretching of the $\mathrm{NH}_{3}$ ligands. These modes tend to give broad absorptions and it is possible that, because of their low IR intensity, they fall below the detection threshold of our apparatus. However, these modes are common in the IR spectra of most of the species concerned, and consequently are not so important for the purpose of structural recognition. On the other hand, the IRMPD spectrum shows important features which confirm the structural assessments deduced from fingerprint region. The major band at $3672 \mathrm{~cm}^{-1}$ can been assigned to the $\mathrm{PO}-\mathrm{H}$ and $\mathrm{O}\left(3^{\prime}\right)-\mathrm{H}$ stretching modes computed at 3673.6 and $3674.1 \mathrm{~cm}^{-1}$, respectively, for PtdGMP_D5. The N1-H stretching mode appears at $3422 \mathrm{~cm}^{-1}$ and the broad feature at $3440-3453 \mathrm{~cm}^{-1}$ can be assigned to the symmetric $\mathrm{NH}_{2}$ stretching mode, that are expected at 3424 and $3446 \mathrm{~cm}^{-1}$, respectively, for PtdGMP_D5. The small, broad feature with a maximum at $2984 \mathrm{~cm}^{-1}$ is important to characterize the complex at $\mathrm{m} / \mathrm{z}$ 574-578, formed in aqueous solution. It is reproduced only in the calculated spectra of PtdGMP_D4-6, and therefore is highly diagnostic. It is due to the stretch of the $\mathrm{N}-\mathrm{H}$ bond involved in the strong hydrogen bond between the ammonia ligand of the cis-[Pt( $\left.\left(\mathrm{NH}_{3}\right)_{2}\right]^{2+}$ unit and the carbonyl oxygen of the guanine, and calculated at $2968 \mathrm{~cm}^{-1}$. OPO experiments may also provide some information about the nucleobase orientation within the complex. As can be observed from the calculated spectra reported in Figure 3, the position of the PO-H stretch is the same for all the species considered, while that of the OH hydroxyl changes. Within the PtdGMP_Dn family, the 
$\mathrm{O}\left(3^{\prime}\right)-\mathrm{H}$ stretch and the PO-H stretch present strictly close frequencies only in conformers D5 and D4, the ones characterized by a syn configuration (figure $\mathbf{3}\left(\mathbf{b}^{\prime}, \mathbf{d}^{\prime}\right)$ ).

In summary, IRMPD experiments in both spectral ranges unambiguously show that gaseous cis- $\left[\mathrm{Pt}\left(\mathrm{NH}_{3}\right)_{2}\left(5^{\prime}-\mathrm{dGMP}-\mathrm{H}\right)\right]^{+}$ions exhibit a macrochelate structure resulting from the simultaneous interaction of the metal with both the N7 atom of guanine and the phosphate group. Their structure is therefore similar to those characterized in solution by NMR spectroscopy. ${ }^{8,9}$ Note that unlike what was postulated from calculations in these studies, the best agreement is presently obtained for macrochelates having a North sugar conformation (PtdGMP_D4 and PtdGMP_D5) and a syn orientation of guanine.

\subsection{IRMPD spectroscopy of $c i s-\left[\operatorname{PtCl}\left(\mathrm{NH}_{3}\right)_{2}\left(5^{\prime}-\mathrm{dGMP}\right)\right]^{+}$}

As in the case of the $c i s-\left[\mathrm{Pt}\left(\mathrm{NH}_{3}\right)_{2}\left(5^{\prime}-\mathrm{dGMP}-\mathrm{H}\right)\right]^{+}$complex, the whole isotopic pattern at $\mathrm{m} / \mathrm{z}$ 610-614 corresponding to the $c i s-\left[\mathrm{PtCl}\left(\mathrm{NH}_{3}\right)_{2}\left(5^{\prime}-\mathrm{dGMP}\right)\right]^{+}$complex was isolated in the cell of the mass spectrometer in order to be submitted to IRMPD spectroscopy. Photofragmentation of $c i s-\left[\mathrm{PtCl}\left(\mathrm{NH}_{3}\right)_{2}\left(5^{\prime}-\mathrm{dGMP}\right)\right]^{+}$occurs along three different channels (Supporting Information, Figure S2). The main one is associated with loss of $\mathrm{HCl}$ giving rise to the cis$\left[\mathrm{Pt}\left(\mathrm{NH}_{3}\right)_{2}\left(5^{\prime}-\mathrm{dGMP}-\mathrm{H}\right)\right]^{+}$complex (cluster at $\mathrm{m} / \mathrm{z}$ 574-578), which in turn gives four further fragments at $m / z$ 556-559, 539-543, 522-526, 441-445, as already discussed in the previous section (vide supra). The second channel corresponds to the loss of ammonia, to generate the cluster at $\mathrm{m} / \mathrm{z}$ 593-597. The last fragmentation channel involves the cleavage of the $\mathrm{N}$ glycosidic bond, presumably leading to the $c$ is $-\left[\mathrm{PtCl}\left(\mathrm{NH}_{3}\right)_{2}(\mathrm{G})\right]^{+}$complex (cluster at $\mathrm{m} / \mathrm{z}$ 414418), which in turn expels ammonia to yield $c i s-\left[\mathrm{PtCl}\left(\mathrm{NH}_{3}\right)(\mathrm{G})\right]^{+}$at $m / z, 397-401$. These two last fragment ions suggest that the preferred site of platination on 5'-dGMP remains the guanine residue. 
This last photofragmentation channel and the calculations carried out for the cis- $\left[\mathrm{Pt}\left(\mathrm{NH}_{3}\right)_{2}\left(5^{\prime}-\right.\right.$ dGMP)-H $]^{+}$complex, which demonstrate the greater affinity of cis- $\left[\mathrm{Pt}\left(\mathrm{NH}_{3}\right)_{2}\right]^{+}$for the nucleobase rather than for the phosphate group, led us to limit our computational survey to structures just involving platination onto guanine. A detailed description (coordination site, orientation of the base, configuration of the sugar ring, and intramolecular hydrogen bonds) of all the species investigated is given in the Supporting Information. As shown in Figure S4, most of the geometries are characterized by bonding of platinum onto the N7 position of guanine. For the sake of comparison, bonding of Pt with N3 has also been considered, yielding the PtCldGMP_Fn family of isomers. Though characterized as local minima, these species are much less stable than the the N7-bonded structures.

Optimized geometries of representative structures of cis-[PtCl( $\left(\mathrm{NH}_{3}\right)_{2}\left(5^{\prime}\right.$-dGMP $\left.)\right]^{+}$are gathered in Figure 4, together with their relative free energies at 298K. This last photofragmentation channel and the calculations carried out for the cis- $\left[\mathrm{Pt}\left(\mathrm{NH}_{3}\right)_{2}\left(5^{\prime}\right.\right.$-dGMP$\mathrm{H})]^{+}$complex, which demonstrate the greater affinity of $c i s-\left[\mathrm{Pt}\left(\mathrm{NH}_{3}\right)_{2}\right]^{+}$for the nucleobase rather than for the phosphate group, led us to limit our computational survey to structures just involving platination onto guanine. A detailed description (coordination site, orientation of the base, configuration of the sugar ring, and intramolecular hydrogen bonds) of all the species investigated is given in the Supporting Information. As shown in Figure S5, most of the geometries are characterized by bonding of platinum onto the N7 position of guanine. Optimized geometries of representative structures of cis-[PtCl( $\left.\left(\mathrm{NH}_{3}\right)_{2}\left(5^{\prime}-\mathrm{dGMP}\right)\right]^{+}$are gathered in Figure 4, together with their relative free energies at 298K.

\section{$<$ Figure 4 >}


The three most stable forms (PtCldGMP_En, PtCldGMP_B2) share similar characteristics, which can be described as follows: coordination of cis-[PtCl$\left.\left(\mathrm{NH}_{3}\right)_{2}\right]^{+}$onto the $\mathrm{N} 7$ site of guanine, North sugar conformation, and the same ammonia ligand engaged in two hydrogen bonds, one with an oxygen of the phosphate group and the second one with the carbonyl oxygen (O6) of guanine. The global minimum is PtCldGMP_E1, where a third hydrogen bond between the phosphate group and the oxygen atom of the deoxyribose moiety $\left(\mathrm{O}^{\prime} 1\right)$ can be also envisaged. This latter hydrogen bond provides additional stabilization (by ca. $13 \mathrm{~kJ}$ mol $^{-1}$ ). Comparison of PtCldGMP_E2 and PtCldGMP_B2 shows that the nucleobase orientation has no noticeable effect on the stability for a given configuration.

In all the other configurations investigated, the ammonia ligand is involved in a single hydrogen bond with O6. Slightly less stable are the PtCldGMP_C1 and PtCldGMP_C2 structures. These forms are also folded thanks to the presence of a hydrogen bond between the phosphate group and the amino group of guanine. Such hydrogen bonding requires the guanine to adopt a syn orientation, and has already been experimentally observed for deprotonated 5'-dGMP. ${ }^{32,53}$ A brief description of some other representative structure for cis$\left[\mathrm{PtCl}\left(\mathrm{NH}_{3}\right)_{2}\left(5^{\prime}-\mathrm{dGMP}\right)\right]^{+}$complex is provided in the Supporting Information.

PtCldGMP_A1 and PtCldGMP_A2 are characterized by a weak hydrogen bond between one hydrogen of the phosphate group and the chlorine ligand. These two latter structures are less stable than PtCldGMP_E1 by about $30 \mathrm{~kJ} \mathrm{~mol}^{-1}$. Finally, the least stable optimized forms are PtCldGMP_D1 and PtCldGMP_D2. In these species, the phosphate group is hydrogen bonded to the O3' hydroxyl group and no longer interacts with the cis$\left[\mathrm{PtCl}\left(\mathrm{NH}_{3}\right)_{2}\right]^{+}$moiety, resulting in a significant destabilization $\left(+57 \mathrm{~kJ} \mathrm{~mol}^{-1}\right.$-with the respect to the global minimum). 
The IRMPD spectra of $c$ is-[PtCl$\left(\mathrm{NH}_{3}\right)_{2}\left(5^{\prime} \text {-dGMP) }\right]^{+}$ions in both spectral ranges, namely 700 $1900 \mathrm{~cm}^{-1}$ and $2850-3700 \mathrm{~cm}^{-1}$, are plotted in Figures 5a and 5a',respectively, together with the vibrational spectra computed for the stable species displayed in Figure 5.

\section{$<$ Figure 5 >}

In the fingerprint region the experimental spectrum of cis-[PtCl( $\left(\mathrm{NH}_{3}\right)_{2}\left(5^{\prime} \text {-dGMP) }\right]^{+}$shows eight pronounced features at 927, 964, 1095, 1275, 1300, 1582, 1632 and $1725 \mathrm{~cm}^{-1}$, and other minor bands at 1009, 1038, 1156, 1214,1422 and $1533 \mathrm{~cm}^{-1}$. Comparing this experimental spectrum with calculated IR spectra (fig $\mathbf{5 b}$-e), the best agreement is obtained with either PtCldGMP_En $(\mathrm{n}=1,2)$ structures. The experimental IRMPD features are listed in Table 2 together with the IR bands calculated for PtCldGMP_E2. As previously observed for cis-[Pt( $\left(\mathrm{NH}_{3}\right)_{2}\left(5^{\prime} \text {-dGMP-H) }\right]^{+}$(vide supra) and cis-[PtCl$\left.\left(\mathrm{NH}_{3}\right)_{2}(\mathrm{G})\right]^{+}$complexes, ${ }^{54}$ the IRMPD spectrum of cis-[PtCl( $\left.\left(\mathrm{NH}_{3}\right)_{2}\left(5^{\prime}-\mathrm{dGMP}\right)\right]^{+}$presents the three characteristic strong features (here at 1582, 1632 and $1725 \mathrm{~cm}^{-1}$ ), attributed to the $\mathrm{NH}_{2}$ scissoring, $\mathrm{NH}_{3}$ and $\mathrm{N}^{\prime} \mathrm{H}_{3}$ scissoring modes, and the $\mathrm{C} 6=\mathrm{O}$ stretching modes, and computed at 1579,1635 and $1714 \mathrm{~cm}^{-}$

1, respectively. Again, the $\mathrm{C}=\mathrm{O}$ stretch is red-shifted with respect to an unperturbed $\mathrm{C}=\mathrm{O}$ stretching mode. On the other hand, it appears slightly blue-shifted when compared to the frequency of this mode for both cis-[Pt( $\left.\left.\mathrm{NH}_{3}\right)_{2}\left(5^{\prime}-\mathrm{dGMP}-\mathrm{H}\right)\right]^{+}\left(1701 \mathrm{~cm}^{-1}\right)$ and cis$\left[\operatorname{PtCl}\left(\mathrm{NH}_{3}\right)_{2}(\mathrm{G})\right]^{+}\left(1718 \mathrm{~cm}^{-1}\right)$ ions. This point appears even more clearly by comparing the energy gap between the two adjacent bands corresponding to $\mathrm{NH}_{2}$ scissoring and $\mathrm{C}=\mathrm{O}$ stretch. This gap is about $74 \mathrm{~cm}^{-1}$ for cis- $\left[\mathrm{Pt}\left(\mathrm{NH}_{3}\right)_{2}\left(5^{\prime}-\mathrm{dGMP}-\mathrm{H}\right)\right]^{+}, 81 \mathrm{~cm}^{-1}$ for $c i s-\left[\operatorname{PtCl}\left(\mathrm{NH}_{3}\right)_{2}(\mathrm{G})\right]^{+}$ and increases up to $93 \mathrm{~cm}^{-1}$ for $c i s-\left[\mathrm{PtCl}\left(\mathrm{NH}_{3}\right)_{2}\left(5^{\prime}-\mathrm{dGMP}\right)\right]^{+}$. This effect can be interpreted by the fact that in the latter complex, the ammonia ligand is involved in two different hydrogen 
bonds, as shown in Figure 4 (PtCldGMP_En and PtCldGMP_B2), resulting in the weakening in the $\mathrm{H}_{2} \mathrm{~N}-\mathrm{H}^{\cdots} \mathrm{O}=\mathrm{C}$ hydrogen bond. Consequently, the double bond character of C6=O decreases to a lesser extent, and the carbonyl stretch is measured at higher energy with respect to the other complexes. This effect is also illustrated by Figure S6 (Supporting Information), which compares the experimental IRMPD spectra of both cis-[Pt( $\left.\mathrm{NH}_{3}\right)_{2}\left(5^{\prime}-\right.$ $\mathrm{dGMP}-\mathrm{H})]^{+}$and cis-[PtCl$\left.\left(\mathrm{NH}_{3}\right)_{2}\left(5^{\prime}-\mathrm{dGMP}\right)\right]^{+}$in the fingerprint region. Conversely, the $\mathrm{C} 6=\mathrm{O}$ stretching mode is expected at $1693 \mathrm{~cm}^{-1}$ for PtCldGMP_C1 (Figure 5), in which the ammonia ligand is solely hydrogen-bonded with O6.

The broad feature around $1290 \mathrm{~cm}^{-1}$ comprises two peaks at 1275 and $1300 \mathrm{~cm}^{-1}$, and a shoulder at $1250 \mathrm{~cm}^{-1}$. According to our calculations, the first one can be assigned to the calculated band centered at $1290 \mathrm{~cm}^{-1}$, formed by the convolution of three different vibrational modes, namely $\mathrm{P}=\mathrm{O}$ stretching modes at 1285 and $1292 \mathrm{~cm}^{-1}$, and the umbrella bending mode of the $\mathrm{N}^{\prime} \mathrm{H}_{3}$ ligand (not involved in the hydrogen bonding) at $1289 \mathrm{~cm}^{-1}$. The second feature at $1300 \mathrm{~cm}^{-1}$ may correspond to the convolution of two vibrational modes, N1$\mathrm{H}$ bending and $\mathrm{NH}_{3}$ umbrella modes, computed at 1319 and ca $1322 \mathrm{~cm}^{-1}$, respectively. The feature at $1095 \mathrm{~cm}^{-1}$ is also found in the IRMPD spectrum of cis-[ $\left.\mathrm{Pt}\left(\mathrm{NH}_{3}\right)_{2}\left(5^{\prime}-\mathrm{dGMP}-\mathrm{H}\right)\right]^{+}$ and may be attributed to both $\mathrm{C}^{\prime}-\mathrm{H}$ and $\mathrm{C}^{\prime}-\mathrm{OH}$ bending modes and the $\mathrm{P}-\mathrm{OC}$ stretching mode. In agreement with this assignment, this band is not present in the experimental IRMPD spectrum of cis-[PtCl$\left.\left(\mathrm{NH}_{3}\right)_{2}(\mathrm{G})\right]^{+} .{ }^{54}$ Conversely, the partially-resolved bands with the two maxima at 927 and $964 \mathrm{~cm}^{-1}$ are not detected for the $c i s-\left[\mathrm{Pt}\left(\mathrm{NH}_{3}\right)_{2}\left(5^{\prime}-\mathrm{dGMP}\right)-\mathrm{H}^{+}\right]^{+}$adduct (Figure 2), and can be interpreted as the convolution of the of $\mathrm{P}-\mathrm{OH}$ stretching and bending modes calculated at $909-910 \mathrm{~cm}^{-1}$ for the fomer, and the stretching P-OC mode combined with the furanose ring breathing expected at $959 \mathrm{~cm}^{-1}$ for the latter. 
The cis- $\left[\mathrm{PtCl}\left(\mathrm{NH}_{3}\right)_{2}\left(5^{\prime}-\mathrm{dGMP}\right)\right]^{+}$ions have also been examined in the $\mathrm{X}-\mathrm{H}(\mathrm{X}=\mathrm{C}, \mathrm{N}, \mathrm{O})$ stretching region from 2800 to $3800 \mathrm{~cm}^{-1}$. As reported in Figure 5a', cis- $\left[\mathrm{PtCl}\left(\mathrm{NH}_{3}\right)_{2}\left(5^{\prime}-\right.\right.$ $\left.\mathrm{dGMP}^{+}\right]^{+}$presents three major absorptions, observed at 3427,3450 and $3668 \mathrm{~cm}^{-1}$. Other weaker but still significant features are detected at 3356,3386 , and $3558 \mathrm{~cm}^{-1}$. Based on a comparison with the calculated IR spectra reported in Figure 5b'-e', quite a good agreement is found between the experimental spectrum and the IR spectrum of conformer PtCldGMP_E2 and also with PtCldGMP_B2. The main feature at $3668 \mathrm{~cm}^{-1}$ can be assigned to the convolution of three active modes combining $\mathrm{P}-\mathrm{OH}$ and the $\mathrm{O} 3^{\prime}-\mathrm{H}$ stretches (computed at 3667 and $3670 \mathrm{~cm}^{-1}$ ). The two absorptions at $3450 \mathrm{~cm}^{-1}$ and $3558 \mathrm{~cm}^{-1}$ are due to the symmetric and asymmetric stretches of $\mathrm{NH}_{2}$, expected at 3446 and $3560 \mathrm{~cm}^{-1}$, respectively, for PtCldGMP_E2. The band at $3427 \mathrm{~cm}^{-1}$ corresponds to the N1-H stretching mode expected at $3425 \mathrm{~cm}^{-1}$. The two weak absorptions at 3356 and $3386 \mathrm{~cm}^{-1}$ are consistent with the asymmetric stretching modes of the $\mathrm{N}^{\prime} \mathrm{H}_{3}$ ligand, estimated at 3359 and $3395 \mathrm{~cm}^{-1}$, respectively.

Furthermore, the IRMPD spectrum of $c i s-\left[\mathrm{PtCl}\left(\mathrm{NH}_{3}\right)_{2}\left(5^{\prime}-\mathrm{dGMP}\right)\right]^{+}$shows two broad absorptions, the most important between 3116 and $3219 \mathrm{~cm}^{-1}$, and a second one at ca. 3270 $\mathrm{cm}^{-1}$ (from 3227 to $3294 \mathrm{~cm}^{-1}$ ). The more pronounced one can be assigned to the stretch of $\mathrm{N}$ $\mathrm{H}$ bonds involved in hydrogen bonding. Experimentally, the IRMPD feature for this kind of stretching mode was often found quite weak and also red-shifted with respect to the calculated position (as was observed for example for water solvated clusters ${ }^{55}$, solvated amino acids ${ }^{56}$ or nucleobases $^{57,58}$ and lactic ester derivatives ${ }^{59}$ ) even if their predicted intensities are very high. The most common explanation lies in the anharmonicity of this mode and the ensuing low IRMPD efficiency. Within this broad absorption, two maxima may be discerned at 3144 and at $3177 \mathrm{~cm}^{-1}$, that may be assigned to symmetric and asymmetric N-H stretching mode of the 
two NH bonds of the ammonia ligand involved in two hydrogen bond interactions, calculated at 3146 and $3205 \mathrm{~cm}^{-1}$, respectively. As observed in the fingerprint region, the simultaneous involvement in these two hydrogen bonds by the same ammonia ligand decreases the strength of these interactions with respect to an otherwise single hydrogen bond. Consequently, the covalent $\mathrm{N}-\mathrm{H}$ bonds involved in hydrogen bonding are stronger than the one observed in the case of $c i s-\left[\mathrm{PtCl}\left(\mathrm{NH}_{3}\right)_{2}(\mathrm{G})\right]^{+}$and $c i s-\left[\mathrm{Pt}\left(\mathrm{NH}_{3}\right)_{2}\left(5^{\prime}-\mathrm{dGMP}-\mathrm{H}\right)\right]^{+}$. Therefore, this mode is active at relatively higher frequency, calculated to be half-way between a free $\mathrm{N}-\mathrm{H}$ bond (typically $\left.3340 \mathrm{~cm}^{-1}\right)$ and a N-H bond in a single and strong hydrogen bond $\left(3054 \mathrm{~cm}^{-1}\right)$, as previously observed in the case of $c i s-\left[\mathrm{PtCl}\left(\mathrm{NH}_{3}\right)_{2}(\mathrm{G})\right]^{+}{ }^{7}$ It is worth noting that all other vibrational modes common to both $c i s-\left[\mathrm{PtCl}\left(\mathrm{NH}_{3}\right)_{2}(\mathrm{G})\right]^{+}, \quad$ cis- $\left[\mathrm{Pt}\left(\mathrm{NH}_{3}\right)_{2}\left(5^{\prime}-\mathrm{dGMP}-\mathrm{H}\right)\right]^{+}$and cis$\left[\mathrm{PtCl}\left(\mathrm{NH}_{3}\right)_{2}\left(5^{\prime}-\mathrm{dGMP}\right)\right]^{+}$fall exactly at the same position as reported in Figure S7 (Supporting Information). Interestingly, the PO-H stretch involved in a hydrogen bond with the furanosic oxygen, expected at $3327 \mathrm{~cm}^{-1}$ and pertaining only to PtCldGMP_E1, is missing in our experimental spectrum. Possibly, the second tiny broad absorption found between 3227 and $3294 \mathrm{~cm}^{-1}$ could be associated to this specific mode. However, the calculated spectrum of PtCldGMP_E2 presents also a small absorption at $3269 \mathrm{~cm}^{-1}$ corresponding to the asymmetric $\mathrm{N}-\mathrm{H}$ stretch of $\mathrm{N}^{\prime} \mathrm{H}_{3}$. In either circumstances, it may be safely stated that cis-[PtCl$\left.\left(\mathrm{NH}_{3}\right)_{2}\left(5^{\prime}-\mathrm{dGMP}\right)\right]^{+}$ions generated in solution and analyzed in the gas phase exhibit a chelate structure consistent with the geometry of PtCldGMP_E2 while PtCldGMP_E1 may also contribute, albeit to a minor extent.

In summary, cis- $\left[\mathrm{PtCl}\left(\mathrm{NH}_{3}\right)_{2}\left(5^{\prime}-\mathrm{dGMP}\right)\right]^{+}$ions generated in the gas phase by ESI ionization are characterized by a monodentate interaction of the Platinum onto the N7 position of guanine, like already observed in the gas phase for guanine, ${ }^{7}$ or in solution for $5^{\text {'GMP. }} .^{10,11}$ 
The structures characterized by our IRMPD experiments turn to be rather compact due to the involvement of the same ammoniac ligand in two hydrogen bonds.

\section{Conclusions}

The purpose of this study is to provide an accurate characterization of cis- $\left[\mathrm{Pt}\left(\mathrm{NH}_{3}\right)_{2}\left(5^{\prime}-\right.\right.$ $\mathrm{dGMP}-\mathrm{H})]^{+}$and cis-[PtCl$\left.\left(\mathrm{NH}_{3}\right)_{2}\left(5^{\prime}-\mathrm{dGMP}\right)\right]^{+}$taken as models of the monofunctional adduct between cisplatin and DNA, using IRMPD spectroscopy. Mass spectrometry has the ability to isolate the ions of interest to be submitted to the IR characterization, allowing the study of transient or highly reactive ions such as $c i s-\left[\mathrm{PtCl}\left(\mathrm{NH}_{3}\right)_{2}\left(5^{\prime}-\mathrm{dGMP}\right)\right]^{+}$. The present study has confirmed a macrochelate structure for the $c i s-\left[\mathrm{Pt}\left(\mathrm{NH}_{3}\right)_{2}\left(5^{\prime}-\mathrm{dGMP}-\mathrm{H}\right)\right]^{+}$ion where the $\mathrm{Pt}$ is coordinated both to the N7 position of guanine and to the deprotonated oxygen of the phosphate group, with a North sugar conformation as previously predicted by NMR spectroscopy ${ }^{8,9}$, but at variance with what postulated before the better agreement seems to be with a syn base orientation. In the $c i s-\left[\mathrm{PtCl}\left(\mathrm{NH}_{3}\right)_{2}\left(5^{\prime}-\mathrm{dGMP}\right)\right]^{+}$where platinum ion allows a only one coordination site to 5'-dGMP, the coordination is direct only onto the N7 position of the guanine, with one of the two ammonia ligands involved in two hydrogen bonds, one with an oxygen of the phosphate group and the second one with the carbonyl oxygen (O6) of guanine. This motif causes a somewhat low strength in both hydrogen bonds, as reflected in the IRMPD spectra: the carbonyl stretch is active at higher energy than in cis-[ $\operatorname{Pt}\left(\mathrm{NH}_{3}\right)_{2}\left(5^{\prime}-\right.$ dGMP-H) $]^{+}$and the stretch of the $\mathrm{N}-\mathrm{H}$ bond involved in the hydrogen bond appears to be active at a frequency in half-way between that of a free $\mathrm{N}-\mathrm{H}$ and that of a $\mathrm{N}-\mathrm{H}$ involved in a strong hydrogen bond.

\section{Acknowledgements}


The authors wish to thank the CLIO team (J. M. Ortega, C. Six, G. Perilhous, J. P. Berthet) as well as P. Maître, V. Steinmetz and A. Di Marzio for their support during the experiments. JYS is grateful to the computational centre of the Universidad Autonoma de Madrid for computing facilities. Financial support has been provided by the Italian MIUR (Prin project 2009W2W4YF_004) and by the European Union (project IC019-12 entitled 'The interaction of cisplatin with nucleic acids: an approach by IRMPD spectroscopy. II')

\section{Supporting Information Available}

Detailed photofragmentation mass spectra of ions under examination; all computed structures for $c i s-\left[\mathrm{Pt}\left(\mathrm{NH}_{3}\right)_{2} \mathrm{Cl}\left(5^{\prime}-\mathrm{dGMP}\right)\right]^{+}$and $c i s-\left[\mathrm{Pt}\left(\mathrm{NH}_{3}\right)_{2}\left(5^{\prime}-\mathrm{dGMP}-\mathrm{H}\right)\right]^{+}$are gathered into a supporting information. This material is available free of charge via the Internet at http://pubs.acs.org/ 
Table 1: Experimental spectrum of the $\operatorname{cis}-\left[\mathrm{Pt}\left(\mathrm{NH}_{3}\right)_{2}\left(5^{\prime}-\mathrm{dGMP}-\mathrm{H}\right)\right]^{+}$complex and computed vibrational modes for the PtdGMP_D5 isomer.

\begin{tabular}{|c|c|c|}
\hline \multicolumn{2}{|c|}{ Wavenumber $\left(\mathrm{cm}^{-1}\right)$} & \multirow[t]{2}{*}{ Vibrational mode $^{b}$} \\
\hline IRMPD & Calculated $^{\mathrm{a}}$ & \\
\hline \multicolumn{3}{|c|}{ Fingerprint region (FEL) } \\
\hline \multirow{4}{*}{902} & $855(103)$ & $\beta \mathrm{N} 8 \mathrm{H}+v \mathrm{POH}$ \\
\hline & $861(90)$ & $v \mathrm{POH}$ \\
\hline & $881(81)$ & $\mathrm{NH}_{3}$ Twist \\
\hline & $893(124)$ & $v$ P-OC5' + Furanosic ring breathing \\
\hline 931 & $935(96)$ & Furanosic ring breathing \\
\hline \multirow{4}{*}{1021} & $976(206)$ & $v \mathrm{O}-\mathrm{P}=\mathrm{O}-\mathrm{Pt}+v \mathrm{P}-\mathrm{O} 5$ \\
\hline & $991(325)$ & $v \mathrm{P}=\mathrm{O}-\mathrm{Pt}+\beta \mathrm{POH}$ \\
\hline & $994(107)$ & Furanosic ring breathing \\
\hline & $1019(71)$ & Furanosic ring breathing $+\mathrm{C}\left(5^{\prime}\right) \mathrm{H}_{2}$ Rock \\
\hline \multirow{4}{*}{1095} & $1068(125)$ & $\mathrm{NH}_{2}$ Rock $+v \mathrm{C}^{\prime}{ }^{\prime} \mathrm{OH}$ \\
\hline & $1071(82)$ & $\mathrm{NH}_{2}$ Rock \\
\hline & $1085(138)$ & Furanosic ring breathing $+\mathrm{C}\left(5^{\prime}\right) \mathrm{H}_{2}$ Rock \\
\hline & $1098(44)$ & $v$ C4'C5' \\
\hline 1169 & $1153(78)$ & $v \mathrm{C} 6 \mathrm{~N} 1+\beta \mathrm{C} 8 \mathrm{H}$ \\
\hline \multirow{2}{*}{1198} & $1188(96)$ & v C1'N9 \\
\hline & $1224(132)$ & $v \mathrm{C} 8 \mathrm{~N} 9+\beta \mathrm{C}^{\prime} \mathrm{H}$ \\
\hline \multirow{2}{*}{1283} & $1276(164)$ & $v \mathrm{P}=\mathrm{O}$ \\
\hline & $1287(120)$ & $\mathrm{N}^{\prime} \mathrm{H}_{3}$ umbrella \\
\hline \multirow{2}{*}{1320} & $1322(125)$ & $\beta \mathrm{N} 1{ }^{\prime} \mathrm{H}$ \\
\hline & $1329(44)$ & $\beta \mathrm{N} 1$ 'H + guanine ring breathing \\
\hline 1367 & $1350(78)$ & $\mathrm{NH}_{3}$ umbrella \\
\hline 1516 & $1525(65)$ & $\beta \mathrm{C} 8 \mathrm{H}+$ guanine ring breathing \\
\hline \multirow{2}{*}{1582} & $1563(69)$ & $v \mathrm{C} 4-\mathrm{C} 5$ \\
\hline & $1582(333)$ & $\delta \mathrm{NH}_{2}$ Sciss $+v \mathrm{C} 4-\mathrm{N} 3$ \\
\hline \multirow{2}{*}{1627} & $1635(951)$ & $\beta \mathrm{NH}_{2}$ Sciss of $\mathrm{NH}_{2}$ \\
\hline & $1659(115)$ & $\beta \mathrm{NH}_{2}$ Sciss of $\mathrm{NH}_{3}$ \\
\hline 1701 & $1699(594)$ & $v \mathrm{C}=\mathrm{O}$ \\
\hline \multicolumn{3}{|c|}{ X-H stretch region (OPO) } \\
\hline \multirow{3}{*}{$2919-2984$} & 2915 (19) & $v \mathrm{C}\left(5^{\prime}\right) \mathrm{H}_{2}$ sym \\
\hline & $2938(23)$ & $v \mathrm{C}^{\prime}{ }^{\prime} \mathrm{H}+v \mathrm{C}\left(2^{\prime}\right) \mathrm{H}_{2}$ sym \\
\hline & $2968(602)$ & $v \mathrm{~N}-\mathrm{H}$ of $\mathrm{NH}_{3} \cdots \mathrm{O}=\mathrm{C} 6$ \\
\hline 3156 & $3168(26)$ & $\vee \mathrm{C} 8 \mathrm{H}$ \\
\hline- & $3262(26)$ & $v \mathrm{~N}^{\prime} \mathrm{H}_{3}$ sym \\
\hline- & $3337(47)$ & $v \mathrm{NH}_{3}$ asym \\
\hline- & $3358(59)$ & $v \mathrm{~N}^{\prime} \mathrm{H}_{3}$ asym \\
\hline \multirow{2}{*}{3381} & $3395(31)$ & $v \mathrm{~N}^{\prime} \mathrm{H}_{3}$ asym \\
\hline & $3396(38)$ & $v \mathrm{NH}_{3}$ asym \\
\hline 3422 & $3424(63)$ & $v \mathrm{~N} 1-\mathrm{H}$ \\
\hline $3440-3453$ & $3446(203)$ & $v \mathrm{NH}_{2}$ sym \\
\hline$\sim 3557$ & $3560(72)$ & $v \mathrm{NH}_{2}$ asym \\
\hline \multirow{2}{*}{3672} & $3674(165)$ & vOH Phos \\
\hline & $3674(51)$ & $v \mathrm{O}\left(3^{\prime}\right) \mathrm{H}$ \\
\hline
\end{tabular}

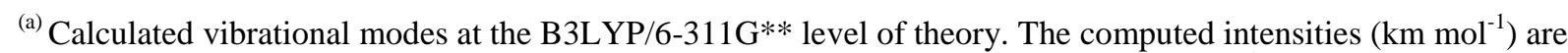
given in parenthesis. In the fingerprint region, bands with intensity lower than $40 \mathrm{~km} \mathrm{~mol}^{-1}$ are not included. 
(b) $\beta=$ bending; $v=$ stretching, Wag = wagging, Rock = rocking, Sciss = scissoring. $\mathrm{NH}_{3}$ denotes the ammonia interacting with the carbonyl group, $\mathrm{N}^{\prime} \mathrm{H}_{3}$ denotes the other ammonia ligand.

Table 2: Experimental spectrum of the cis-[PtCl( $\left.\left(\mathrm{NH}_{3}\right)_{2}\left(5^{\prime}-\mathrm{dGMP}\right)\right]^{+}$complex and computed vibrational modes for the PtCldGMP_E2 isomer

\begin{tabular}{|c|c|c|}
\hline \multicolumn{2}{|c|}{ Wavenumber $\left(\mathrm{cm}^{-1}\right)$} & \multirow[t]{2}{*}{ Vibrational mode $^{\mathrm{b}}$} \\
\hline IRMPD & Calculated $^{\mathrm{a}}$ & \\
\hline \multicolumn{3}{|c|}{ Fingerprint region (FEL) } \\
\hline \multirow{2}{*}{927} & $909(274)$ & $v \mathrm{POH}+\beta \mathrm{POH}$ phosphate \\
\hline & $910(191)$ & $v \mathrm{P}=\mathrm{OH}+\beta \mathrm{POH}$ phosphate (both) \\
\hline \multirow{2}{*}{964} & $959(105)$ & Furanosic ring breathing $+v$ P-OC \\
\hline & $982(61)$ & $v$ P-OC + Furanosic ring breathing \\
\hline 1009 & $1017(74)$ & $\beta \mathrm{POH}+v \mathrm{P}-\mathrm{O}$ \\
\hline \multirow{2}{*}{1038} & $1043(114)$ & $\nu \mathrm{POC}+$ Furanosic ring breathing $\beta \mathrm{POH}$ \\
\hline & $1056(115)$ & $\nu \mathrm{P}-\mathrm{OC}+$ Furanosic ring breathing $\beta \mathrm{POH}$ \\
\hline \multirow{2}{*}{1095} & $1102(172)$ & $\beta \mathrm{C} 4{ }^{\prime}-\mathrm{H}+v \beta \mathrm{C} 3^{\prime}-\mathrm{OH}+v \mathrm{P}-\mathrm{OC}$ \\
\hline & $1115(137)$ & Furanosic ring breathing; $\beta$ C3'O-H n $\sigma$ P-OC \\
\hline \multirow{2}{*}{1156} & $1137(40)$ & $v \mathrm{C} 4{ }^{\prime}-\mathrm{C} 5$ ' $v$ P-OC \\
\hline & $1142(63)$ & Guanine ring breathing $+\beta \mathrm{C} 8-\mathrm{H}$ \\
\hline \multirow{2}{*}{1214} & $1192(52)$ & $\nu \mathrm{N} 9-\mathrm{C} 1{ }^{\prime}+$ Guanine ring breathing $+\beta \mathrm{C} 8-\mathrm{H}$ \\
\hline & $1224(87)$ & $v$ N9-C1' $+\beta \mathrm{C} 8-\mathrm{H}+\beta \mathrm{C} 3{ }^{\prime} \mathrm{O}-\mathrm{H}$ \\
\hline \multirow{5}{*}{$1275-1300$} & $1285(129)$ & $v \mathrm{P}=\mathrm{O}+$ Twisting $\mathrm{C}^{\prime}{ }^{\prime} \mathrm{H} 2$ \\
\hline & $1289(115)$ & $\mathrm{N}^{\prime} \mathrm{H}_{3}{ }^{\prime}$ umbrella \\
\hline & $1292(309)$ & $v \mathrm{P}=\mathrm{O}+\mathrm{C}\left(5^{\prime}\right) \mathrm{H}_{2}$ Twist $\mathrm{C} 5^{\prime} \mathrm{H} 2$ Twist \\
\hline & $1319(126)$ & $\mathrm{NH}_{3}$ umbrella $+\beta \mathrm{N} 1-\mathrm{H}$ \\
\hline & $1322(81)$ & $\mathrm{NH}_{3}$ umbrella \\
\hline 1422 & $1401(41)$ & $\beta \mathrm{C}^{\prime} 1-\mathrm{H}+$ Guanine ring breathing \\
\hline 1533 & $1526(79)$ & Guanine ring breathing $+\beta \mathrm{C} 8-\mathrm{H}$ \\
\hline \multirow{2}{*}{1582} & $1563(71)$ & $\beta$ sciss $\mathrm{NH}_{2}+v \mathrm{C} 4-\mathrm{C} 5$ \\
\hline & $1579(350)$ & $\beta$ sciss $\mathrm{NH}_{2}$ \\
\hline \multirow{4}{*}{1632} & $1620(131)$ & $\beta \mathrm{NH}_{2}$ rock of $\mathrm{NH}_{3}$ \\
\hline & $1633(418)$ & $\beta$ sciss $\mathrm{NH}_{2}+\beta \mathrm{NH}_{2}$ rock N'H $\mathrm{N}_{3}$ \\
\hline & $1635(446)$ & $\beta \mathrm{NH}_{2}$ sciss of $\mathrm{NH}_{2}$ and $\mathrm{NH}_{3}$ \\
\hline & $1664(43)$ & $\beta \mathrm{NH}_{2}$ sciss of $\mathrm{NH}_{3}$ \\
\hline 1725 & $1714(534)$ & $v \mathrm{C}=\mathrm{O}$ \\
\hline \multicolumn{3}{|c|}{ X-H stretch region (OPO) } \\
\hline \multirow{2}{*}{$\begin{array}{c}3116-3210 \\
(3144-3172) \\
\end{array}$} & $3146(358)$ & $v \mathrm{NH}_{3}$ sym double $\mathrm{H}$ Bonded $\mathrm{PO}$ and $\mathrm{C} 6 \mathrm{O}$ \\
\hline & $3205(400)$ & $v \mathrm{NH}_{3}$ asym double $\mathrm{H}$ Bonded $\mathrm{PO}$ and $\mathrm{C} 6 \mathrm{O}$ \\
\hline $\begin{array}{c}(3227-3294) \\
3270 \\
\end{array}$ & $3269(17)$ & $v \mathrm{~N}^{\prime} \mathrm{H}_{3}$ sym \\
\hline 3356 & 3359 (46) & $v \mathrm{~N}^{\prime} \mathrm{H}_{3}$ asym \\
\hline \multirow{2}{*}{3386} & $3394(39)$ & $v \mathrm{~N}^{\prime} \mathrm{H}_{3}$ asym $(2 \mathrm{H})$ \\
\hline & $3396(37)$ & $v \mathrm{NH}_{3}$ not involved in $\mathrm{H}$ bonding \\
\hline 3427 & $3425(58)$ & $\mathrm{VN} 1 \mathrm{H}$ \\
\hline 3450 & $3446(193)$ & $v \mathrm{NH}_{2}$ sym \\
\hline 3558 & $3560(69)$ & $v \mathrm{NH}_{2}$ asym \\
\hline \multirow{3}{*}{3668} & $3667(137)$ & $v$ POH asym (both) \\
\hline & $3670(126)$ & $v$ C3'O-H and $+v$ POH sym (both) \\
\hline & $3670(119)$ & $v$ POH sym (both) and $+v$ C3'O-H \\
\hline
\end{tabular}


(a) Vibrational modes Calculated at the B3LYP/6-311G** level of theory. The computed intensities $\left(\mathrm{km} \mathrm{mol}^{-1}\right)$ are given in parenthesis. In the fingerprint region, bands with intensity lower than $40 \mathrm{~km} \mathrm{~mol}^{-1}$ are not included.

(b) $\beta=$ bending; $v=$ stretching, Wag = wagging, Rock = rocking, Sciss = scissoring. $\mathrm{NH}_{3}$ denotes the ammonia interacting with the carbonyl group, $\mathrm{N}^{\prime} \mathrm{H}_{3}$ denotes the ammonia located near the chlorine atom.

\section{Captions for Figures}

Figure 1. Structure of $2^{\prime}$-deoxyguanosine-5'-monophosphate (here with an anti configuration and a North sugar conformation). $\mathrm{C}$ are in dark grey, $\mathrm{N}$ in blue, $\mathrm{O}$ in red, $\mathrm{P}$ in magenta and $\mathrm{H}$ in light grey.

Figure 2. Geometries and relative free energies $\left(\mathrm{kJ} \mathrm{mol}^{-1}\right)$ for the more stable structures of cis- $\left[\mathrm{Pt}\left(\mathrm{NH}_{3}\right)_{2}\left(5^{\prime}-\mathrm{dGMP}-\mathrm{H}\right)\right]^{+}$ions calculated at the B3LYP/6-311G** level. Distances are in $\AA$.

Figure 3. Figure 3. Experimental IRMPD spectrum of the cis- $\left[\mathrm{Pt}\left(\mathrm{NH}_{3}\right)_{2}\left(5^{\prime}-\mathrm{dGMP}-\mathrm{H}\right)\right]^{+}$ complex (bottom) in both fingerprint (a) and $\mathrm{X}-\mathrm{H}(\mathrm{X}=\mathrm{C}, \mathrm{N}, \mathrm{O})$ stretch (a') regions, compared with the IR spectra of structures reported in Figure 2 computed at the B3LYP/6-311G** level. See text for details

Figure 4. Geometries and relative free energies $\left(\mathrm{kJ} \mathrm{mol}^{-1}\right)$ of representative cis- $\left[\mathrm{PtCl}\left(\mathrm{NH}_{3}\right)_{2}\left(5^{\prime} \text {-dGMP }\right)\right]^{+}$structures calculated at the B3LYP/6-311G** level. Distances are in $\AA$.

Figure 5. Experimental IRMPD spectrum of the cis-[PtCl( $\left.\left(\mathrm{NH}_{3}\right)_{2}\left(5^{\prime}-\mathrm{dGMP}\right)\right]^{+}$complex (bottom) in both fingerprint (a) and $\mathrm{X}-\mathrm{H}(\mathrm{X}=\mathrm{C}, \mathrm{N}, \mathrm{O})$ stretch (a') region compared to IR spectra of representative structures computed at the B3LYP/ 6-311G** level. See text for details. 


\section{Figures}

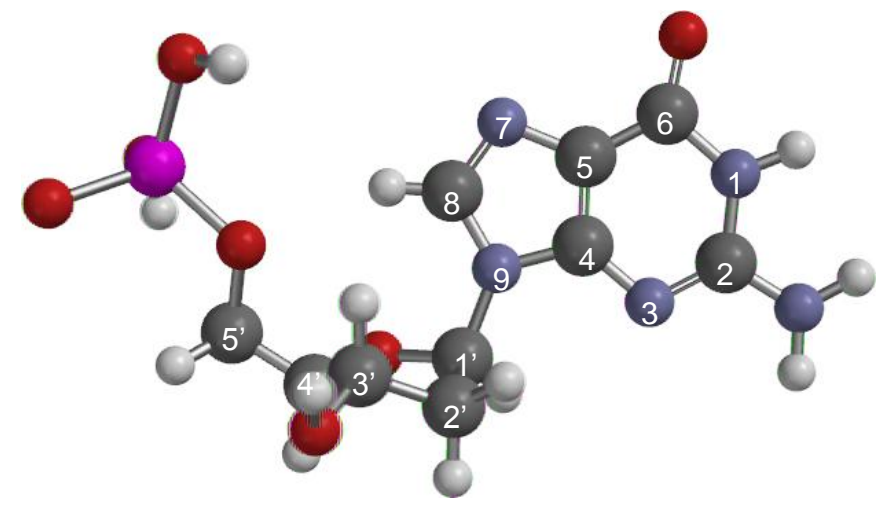

Figure 1. Structure of $2^{\prime}$-deoxyguanosine-5'-monophosphate (here with an anti configuration and a North sugar conformation). $\mathrm{C}$ are in dark grey, $\mathrm{N}$ in blue, $\mathrm{O}$ in red, $\mathrm{P}$ in magenta and $\mathrm{H}$ in light grey. 

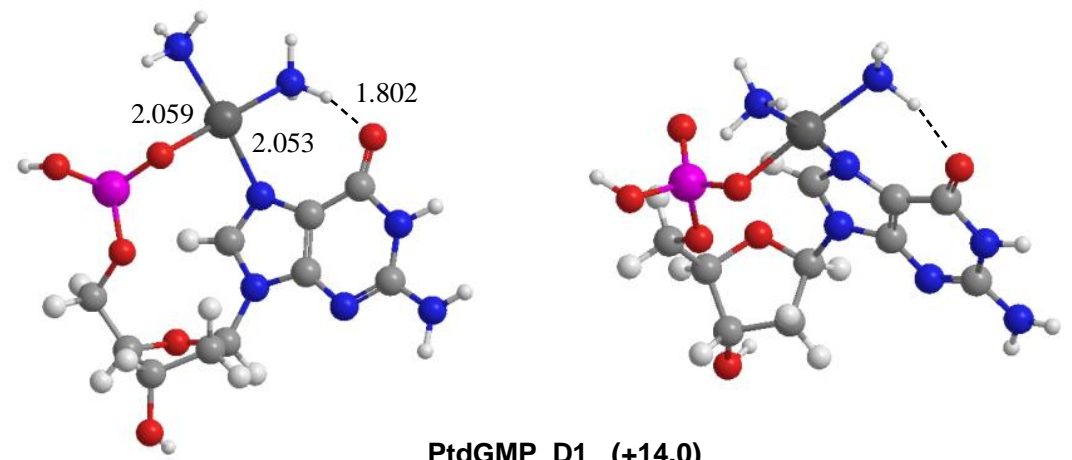

PtdGMP_D1 (+14.0)
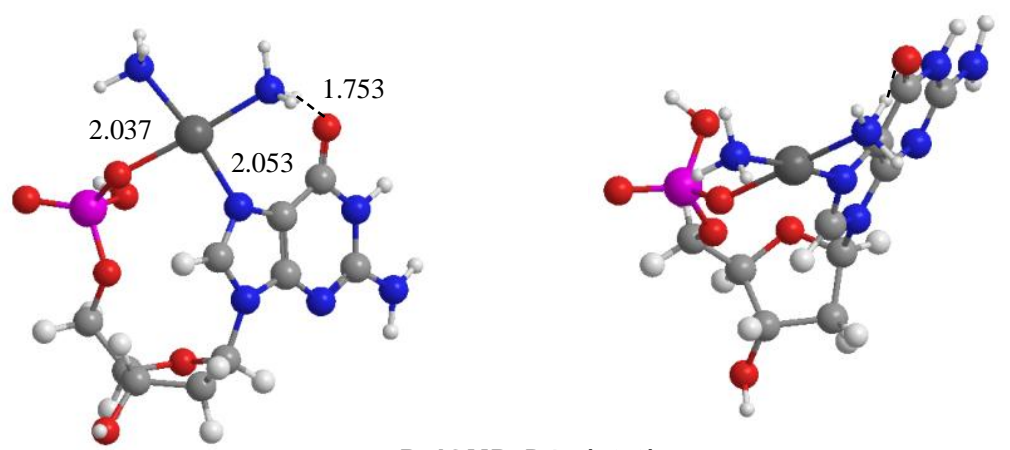

PtdGMP_D4 (+3.6)
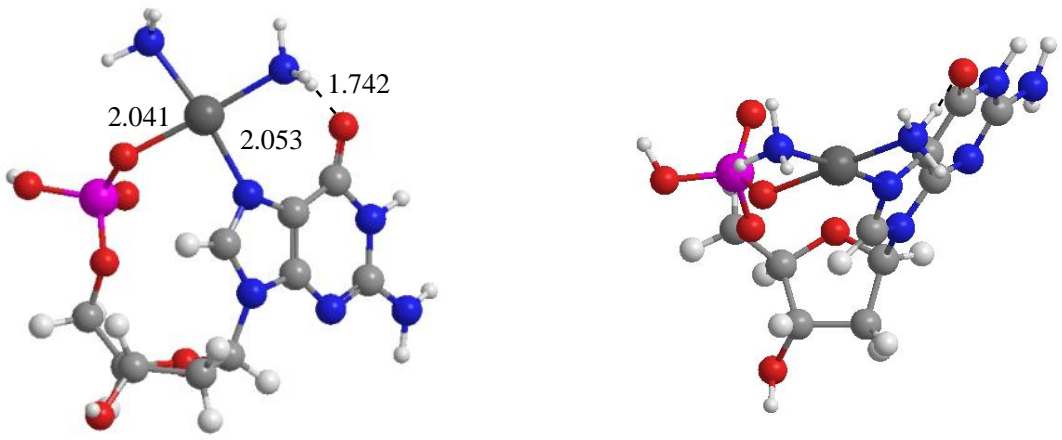

PtdGMP_D5 (0)
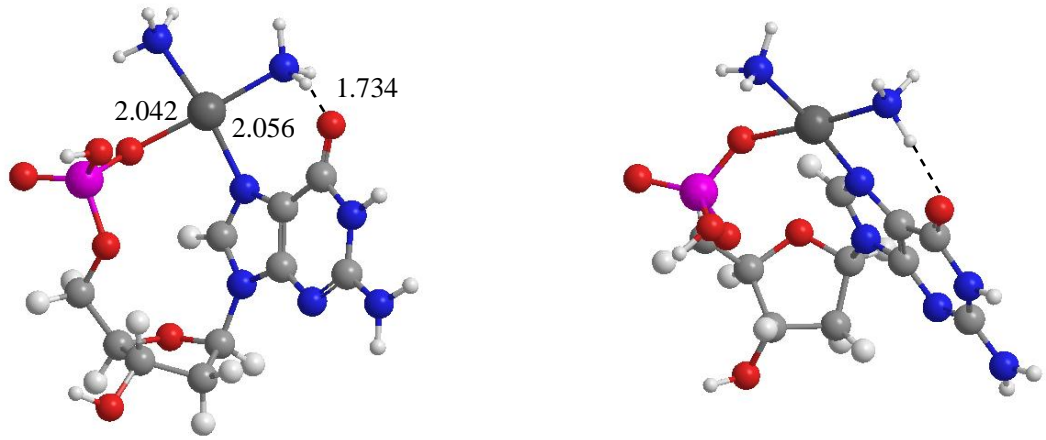

PtdGMP_D6 (+2.6)

Figure 2. Geometries and relative free energies $\left(\mathrm{kJ} \mathrm{mol}^{-1}\right)$ for the most stable structures of cis$\left[\mathrm{Pt}\left(\mathrm{NH}_{3}\right)_{2}\left(5^{\prime}-\mathrm{dGMP}-\mathrm{H}\right)\right]^{+}$ions calculated at the B3LYP/6-311G** level. Distances are in $\AA$. 

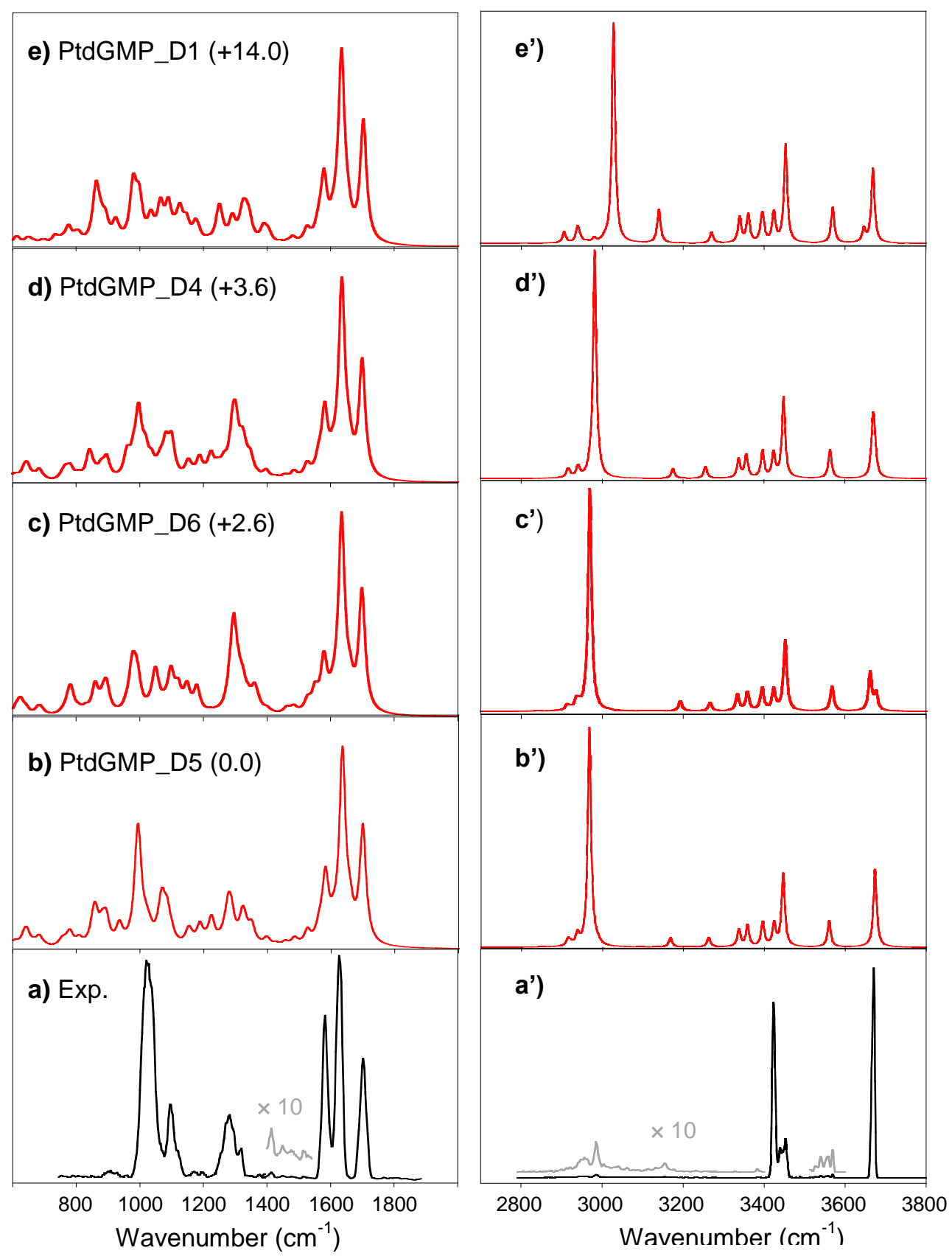

Figure 3. Experimental IRMPD spectrum of the cis- $\left[\mathrm{Pt}\left(\mathrm{NH}_{3}\right)_{2}\left(5^{\prime}-\mathrm{dGMP}-\mathrm{H}\right)\right]^{+}$complex (bottom) in both fingerprint (a) and X-H $(\mathrm{X}=\mathrm{C}, \mathrm{N}, \mathrm{O})$ stretch (a') regions, compared with the IR spectra of structures reported in Figure 2 computed at the B3LYP/6-311G** level. See text for details 

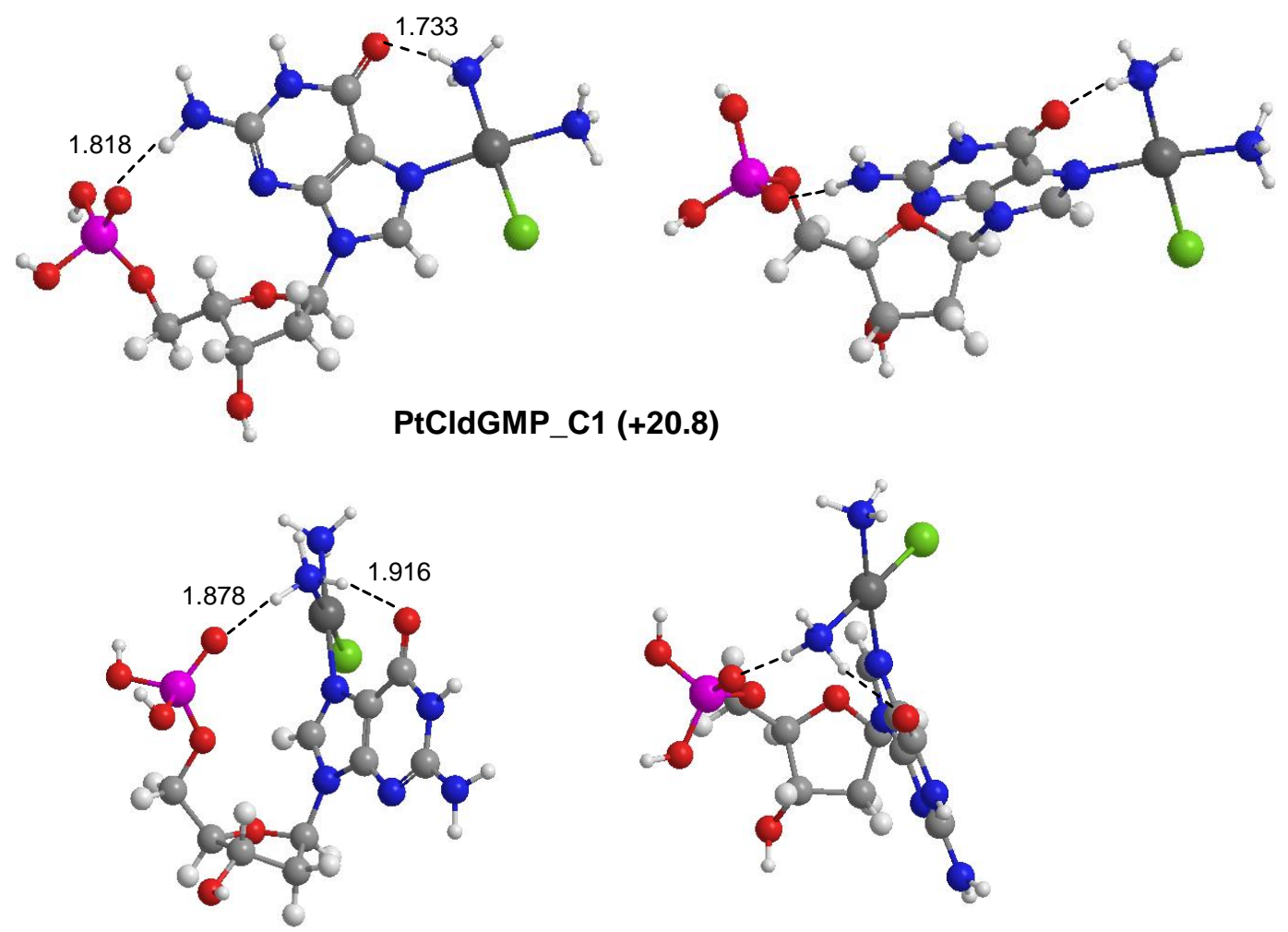

PtCldGMP_B2 (+15.5)
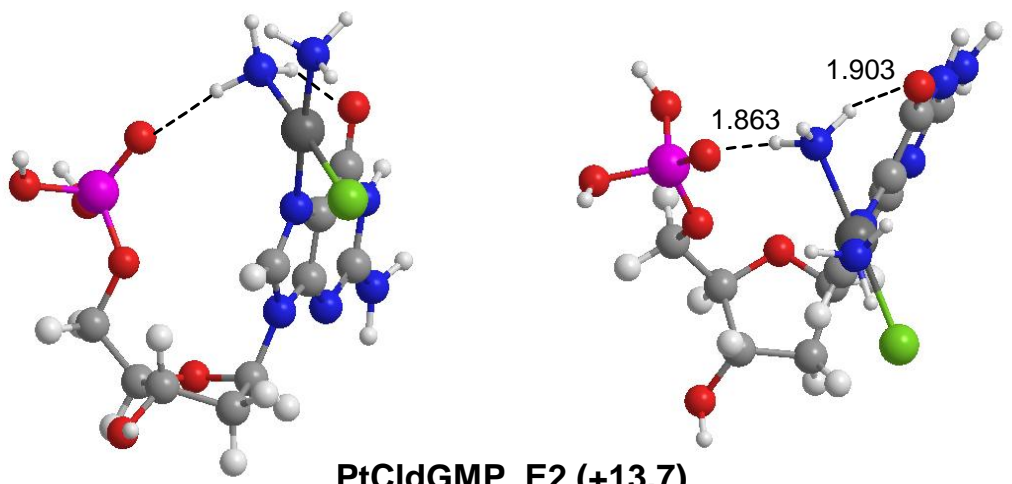

PtCldGMP_E2 (+13.7)
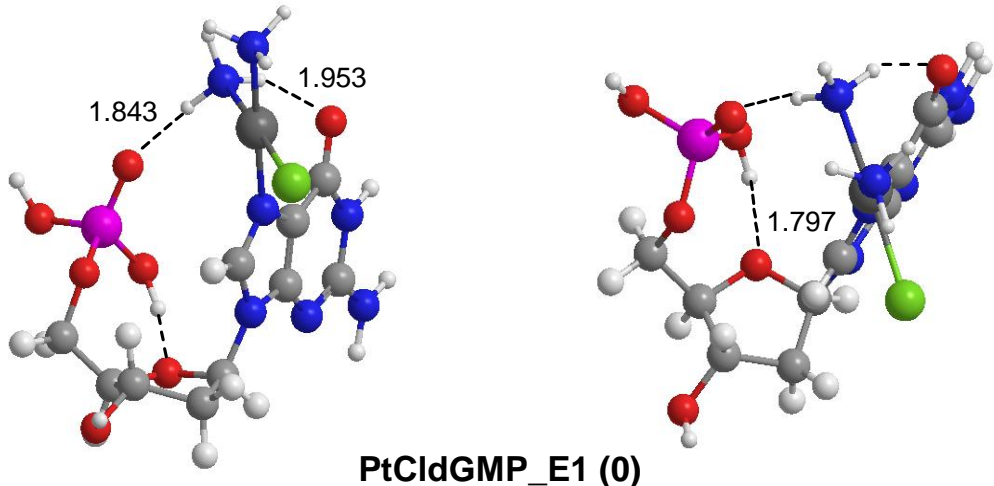

Figure 4. Geometries and relative free energies $\left(\mathrm{kJ} \mathrm{mol}^{-1}\right)$ of representative cis-[PtCl$\left.\left(\mathrm{NH}_{3}\right)_{2}\left(5^{\prime}-\mathrm{dGMP}\right)\right]^{+}$structures calculated at the B3LYP/6-311G** level. Distances are in $\AA$. 

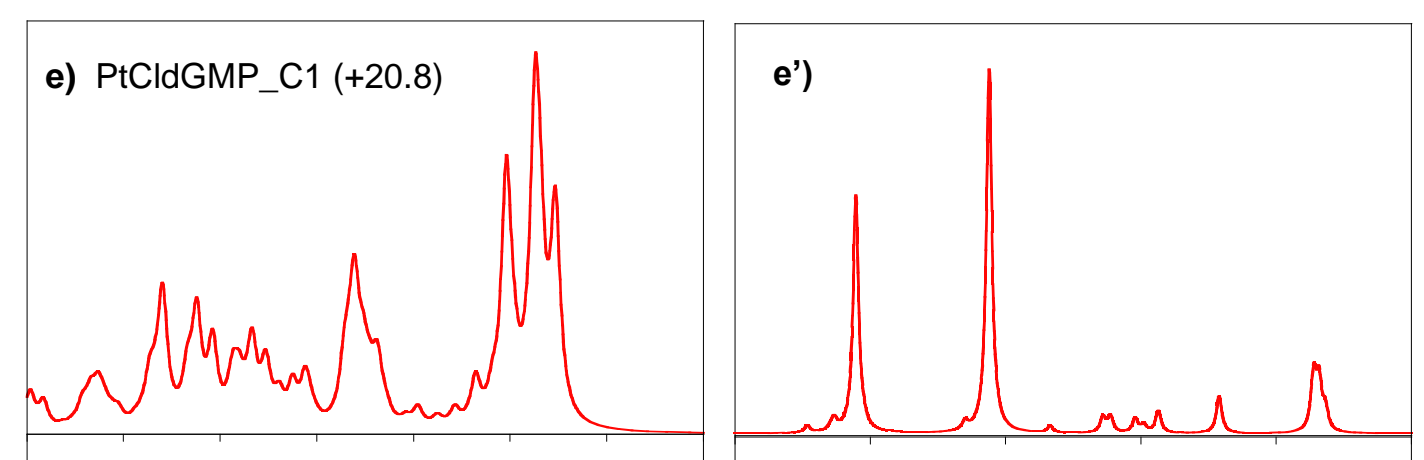

d) PtCldGMP_B2 (+15.5)

d')
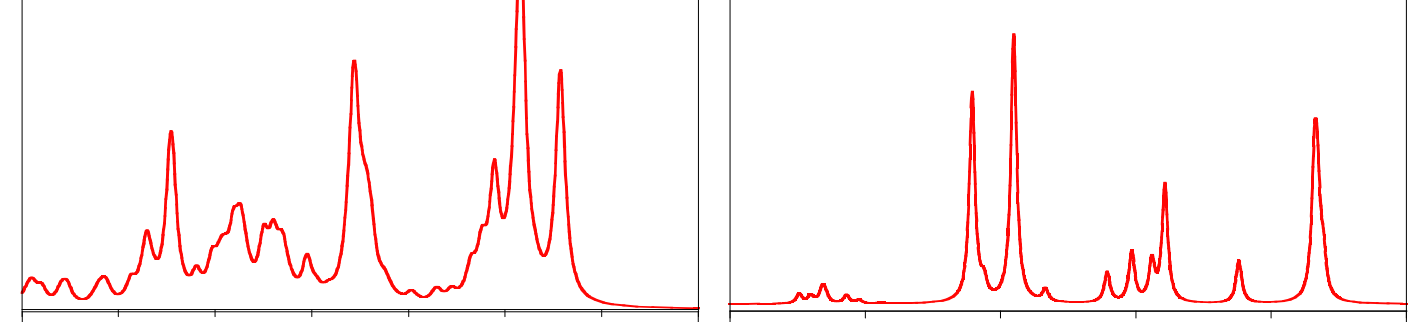

c) PtCldGMP_E2 (+13.7)

c')

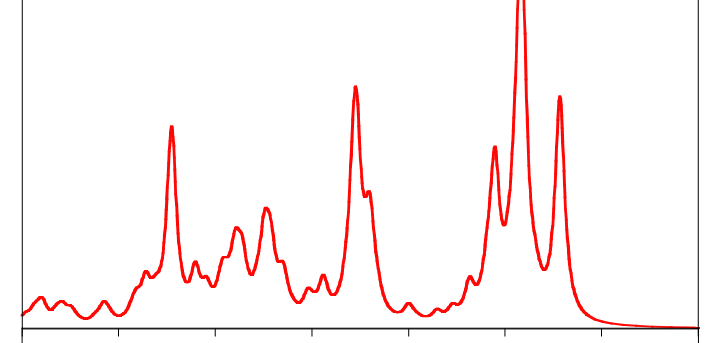

b) PtCldGMP_E1 (0.0)
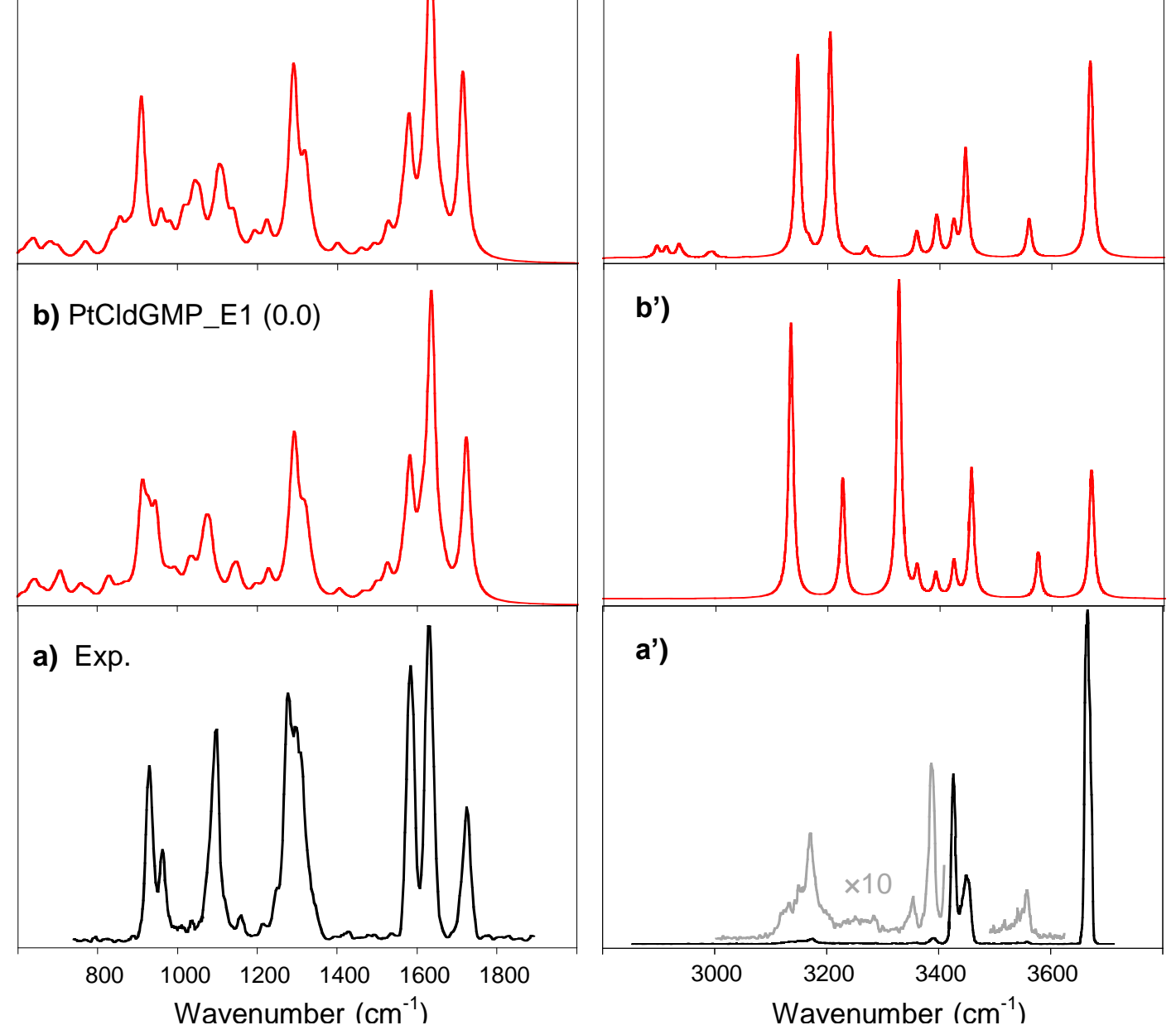

Figure 5. Experimental IRMPD spectrum of the cis-[PtCl( $\left.\left(\mathrm{NH}_{3}\right)_{2}\left(5^{\prime}-\mathrm{dGMP}\right)\right]^{+}$complex (bottom) in both fingerprint (a) and X-H $(\mathrm{X}=\mathrm{C}, \mathrm{N}, \mathrm{O})$ stretch (a') region compared to IR 
spectra of representative structures computed at the B3LYP/ 6-311G** level. See text for details.

\section{Table of Contents Synopsis}

The characterization of $c i s-\left[\mathrm{Pt}\left(\mathrm{NH}_{3}\right)_{2}\left(5^{\prime}-\mathrm{dGMP}-\mathrm{H}\right)\right]^{+}$ion points to macrochelate species resulting from the simultaneous interaction of the metal with both the $\mathrm{N} 7$ atom of the guanine residue and an $\mathrm{O}$ atom of the phosphate group. In contrast, IRMPD spectra of cis$\left[\mathrm{PtCl}\left(\mathrm{NH}_{3}\right)_{2}\left(5^{\prime}-\mathrm{dGMP}\right)\right]^{+}$are consistent with a monodentate complex involving exclusively the N7 position of guanine. Also this species exhibits a compact shape due to the formation of two hydrogen bonds involving the same ammonia ligand.

\section{Table of Contents Graphic}

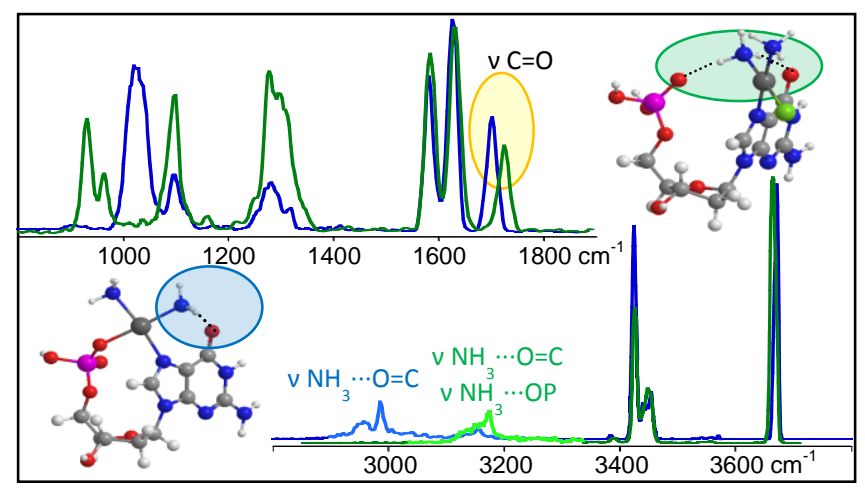

For Table of Contents Only 
References

(1) Rosenberg, B. Cisplatin. Chemistry and Biochemistry of a Leading Anticancer Drug; Verlag Helvetica Chimica Acta: Zürich, 1999.

(2) Sherman, S. E.; Gibson, D.; Wang, A. H.; Lippard, S. J. Science 1985, 230, 412-417.

(3) Sherman, S. E.; Lippard, S. J. Chem. Rev. 1987, 87, 1153-1181.

(4) Sherman, S. E.; Gibson, D.; Wang, A. H. J.; Lippard, S. J. J. Am. Chem. Soc. 1988, $110,7368-7381$.

(5) Bancroft, D. P.; Lepre, C. A.; Lippard, S. J. J. Am. Chem. Soc. 1990, 112, 6860-6871.

(6) De Petris, A.; Ciavardini, A.; Coletti, C.; Re, N.; Chiavarino, B.; Crestoni, M. E.; Fornarini, S. J. Phys. Chem. Lett. 2013, 4, 3631-3635.

(7) Chiavarino, B.; Crestoni, M. E.; Fornarini, S.; Scuderi, D.; Salpin, J. Y. J. Am. Chem. Soc. 2013, 135, 1445-1455.

(8) Reily, M. D.; Marzilli, L. G. J. Am. Chem. Soc. 1986, 108, 8299-8300.

(9) Reily, M. D.; Hambley, T. W.; Marzilli, L. G. J. Am. Chem. Soc. 1988, 110, 29993007.

(10) Dijt, F. J.; Canters, G. W.; Den Hartog, J. H. J.; Marcelis, A. T. M.; Reedijk, J. J. Am. Chem. Soc. 1984, 106, 3644-3647.

(11) Bernersprice, S. J.; Frenkiel, T. A.; Ranford, J. D.; Sadler, P. J. J. Chem. Soc., Dalton Trans. 19922137-2139.

(12) MacAleese, L.; Maitre, P. Mass Spectrom. Rev. 2007, 26, 583-605.

(13) Eyler, J. R. Mass Spectrom. Rev. 2009, 28, 448-467.

(14) Fridgen, T. D. Mass Spectrom. Rev. 2009, 28, 586-607.

(15) Polfer, N. C. Chem. Soc. Rev. 2011, 40, 2211-2221.

(16) Lemaire, J.; Boissel, P.; Heninger, M.; Mauclaire, G.; Bellec, G.; Mestdagh, H.; Simon, A.; Le Caer, S.; Ortega, J. M.; Glotin, F.; Maitre, P. Phys. Rev. Lett. 2002, 89, 273002-273001.

(17) Bakker, J. M.; Besson, T.; Lemaire, J.; Scuderi, D.; Maitre, P. J. Phys. Chem. A 2007, $111,13415-13424$.

(18) Sinha, R. K.; Maitre, P.; Piccirillo, S.; Chiavarino, B.; Crestoni, M. E.; Fornarini, S. Phys. Chem. Chem. Phys. 2010, 12, 9794-9800.

(19) Prell, J. S.; O'Brien, J. T.; Williams, E. R. J. Am. Soc. Mass Spectrom. 2010, 21, 800809.

(20) Lee, C.; Yang, W.; Parr, R. G. Physical Reviews B 1988, 37, 785-789.

(21) Becke, A. D. J. Chem. Phys. 1993, 98, 5648-5652. 
(22) Frisch, M. J.; al., e.; Gaussian09, Revision C.01. See Supporting Information for complete citation. ed.

(23) Hay, P. J.; Wadt, W. R. J. Chem. Phys. 1985, 82, 270-283.

(24) Hay, P. J.; Wadt, W. R. J. Chem. Phys. 1985, 82, 299-310.

(25) Wadt, W. R.; Hay, P. J. J. Chem. Phys. 1985, 82, 284-298.

(26) Stevens, W. J.; Krauss, M.; Basch, H.; Jasien, P. G. Can. J. Chem. 1992, 70, 612-630.

(27) Correia, C. F.; Balaj, P. O.; Scuderi, D.; Maitre, P.; Ohanessian, G. J. Am. Chem. Soc. 2008, 130, 3359-3370.

(28) Scuderi, D.; Correia, C. F.; Balaj, O. P.; Ohanessian, G.; Lemaire, J.; Maitre, P. ChemPhysChem 2009, 10, 1630-1641.

(29) Correia, C. F.; Clavaguera, C.; Erlekam, U.; Scuderi, D.; Ohanessian, G. ChemPhysChem 2008, 9, 2564-2573.

(30) Chiavarino, B.; Crestoni, M. E.; Fornarini, S.; Lanucara, F.; Lemaire, J.; Maitre, P.; Scuderi, D. Int. J. Mass Spectrom. 2008, 270, 111-117.

(31) Lanucara, F.; Crestoni, M. E.; Chiavarino, B.; Fornarini, S.; Hernandez, O.; Scuderi, D.; Maitre, P. RSC Adv. 2013, 3, 12711-12720.

(32) Nei, Y. w.; Hallowita, N.; Steill, J. D.; Oomens, J.; Rodgers, M. T. J. Phys. Chem. A 2013, 117, 1319-1335.

(33) Oomens, J.; Sartakov, B. G.; Meijer, G.; Von Helden, G. Int. J. Mass Spectrom. 2006, 254, 1-19.

(34) Polfer, N. C.; Oomens, J. Mass Spectrom. Rev. 2009, 28, 468-494.

(35) Brodbelt, J. S.; Wilson, J. J. Mass Spectrom. Rev. 2009, 28, 390-424.

(36) Jones, W.; Boissel, P.; Chiavarino, B.; Crestoni, M. E.; Fornarini, S.; Lemaire, J.; Maitre, P. Angew. Chem. Int. Ed. 2003, 42, 2057-2059.

(37) Chiavarino, B.; Crestoni, M. E.; Fornarini, S.; Lemaire, J.; Maitre, P.; MacAleese, L. J. Am. Chem. Soc. 2006, 128, 12553-12561.

(38) Armentrout, P. B.; Rodgers, M. T.; Oomens, J.; Steill, J. D. J. Phys. Chem. A 2008, $112,2248-2257$.

(39) Dopfer, O.; Lemaire, J.; Maitre, P.; Chiavarino, B.; Crestoni, M. E.; Fornarini, S. Int. J. Mass Spectrom. 2006, 249, 149-154.

(40) Wu, R. H.; McMahon, T. B. ChemPhysChem 2008, 9, 2826-2835.

(41) Chiavarino, B.; Crestoni, M. E.; Fornarini, S.; Lanucara, F.; Lemaire, J.; Maitre, P.; Scuderi, D. Chem. Eur. J. 2009, 15, 8185-8195.

(42) Baer, T.; Dunbar, R. C. J. Am. Soc. Mass Spectrom. 2010, 21, 681-693.

(43) Lanucara, F.; Chiavarino, B.; Crestoni, M. E.; Scuderi, D.; Sinha, R. K.; Maitre, P.; Fornarini, S. Inorg. Chem. 2011, 50, 4445-4452.

(44) Salpin, J. Y.; Guillaumont, S.; Ortiz, D.; Tortajada, J.; Maitre, P. Inorg. Chem. 2011, 50, 7769-7778. 
(45) Lanucara, F.; Chiavarino, B.; Crestoni, M. E.; Scuderi, D.; Sinha, R. K.; Maitre, P.; Fornarini, S. Int. J. Mass Spectrom. 2012, 330, 160-167.

(46) Crestoni, M. E.; Chiavarino, B.; Scuderi, D.; Di Marzio, A.; Fornarini, S. J. Phys. Chem. B 2012, 116, 8771-8779.

(47) Lanucara, F.; Scuderi, D.; Chiavarino, B.; Fornarini, S.; Maitre, P.; Crestoni, M. E. J. Phys. Chem. Lett. 2013, 4, $2414-2417$.

(48) Dunbar, R. C.; Oomens, J.; Berden, G.; Lau, J. K. C.; Verkerk, U. H.; Hopkinson, A. C.; Siu, K. W. M. J. Phys. Chem. A 2013, 117, 5335-5343.

(49) Lanucara, F.; Chiavarino, B.; Scuderi, D.; Maitre, P.; Fornarini, S.; Crestoni, M. E. Chemical Communications 2014, 50, 3845-3848.

(50) Salpin, J.-Y.; MacAleese, L.; Chirot, F.; Dugourd, P. Phys. Chem. Chem. Phys. 2014, 16, 14127-14138.

(51) Basch, H.; Krauss, M.; Stevens, W. J.; Cohen, D. Inorg. Chem. 1986, 25, 684-688.

(52) Baik, M. H.; Friesner, R. A.; Lippard, S. J. J. Am. Chem. Soc. 2003, 125, 1408214092.

(53) Gidden, J.; Bowers, M. T. J. Phys. Chem. B 2003, 107, 12829-12837.

(54) Chiavarino, B.; Crestoni, M. E.; Fornarini, S.; Scuderi, D.; Salpin, J.-Y. J. Am. Chem. Soc. 2013, 135, 10877-10877.

(55) Wang, Y. S.; Chang, H. C.; Jiang, J. C.; Lin, S. H.; Lee, Y. T.; Chang, H. C. J. Am. Chem. Soc. 1998, 120, 8777-8788.

(56) Kamariotis, A.; Boyarkin, O. V.; Mercier, S. R.; Beck, R. D.; Bush, M. F.; Williams, E. R.; Rizzo, T. R. J. Am. Chem. Soc. 2006, 128, 905-916.

(57) Bakker, J. M.; Sinha, R. K.; Besson, T.; Brugnara, M.; Tosi, P.; Salpin, J. Y.; Maitre, P. J. Phys. Chem. A 2008, 112, 12393-12400.

(58) Bakker, J. M.; Salpin, J. Y.; Maitre, P. Int. J. Mass Spectrom. 2009, 283, 214-221.

(59) Scuderi, D.; Le Barbu-Debus, K.; Zehnacker, A. Phys. Chem. Chem. Phys. 2011, 13, 17916-17929. 